\title{
LO SUBLIME CÓSMICO EN LA POESÍA DE JUAN MELÉNDEZ VALDÉS*
}

\section{The Cosmic Sublime in the Poetry of Juan Meléndez Valdés}

\author{
Elena de LORENZO ÁLVAREZ \\ Instituto Feijoo de Estudios del Siglo XVIII / Universidad de Oviedo
}

Fecha de recepción: 12/08/2017

Fecha de aceptación definitiva: 15/09/2017

RESUMEN: El propio Meléndez Valdés señala en 1797 que la contemplación de la inmensidad, variedad, orden del universo y cadena de los seres es uno de los principales asuntos de su poesía filosófica y una vía de renovación de la poesía española. Este trabajo identifica tales asuntos con la estética de lo sublime cósmico que signa la poesía filosófica europea contemporánea; rastrea las lecturas en que Meléndez pudo forjar su cultura sobre este motivo, más allá de los poetas europeos de referencia; constata su presencia sostenida en numerosos poemas a lo largo de toda la trayectoria literaria del poeta (1780-1814), y los analiza a la luz del contexto literario, filosófico y religioso de lo sublime cósmico.

Palabras clave: Juan Meléndez Valdés; Poesía filosófica; Sublime Cósmico.

ABSTRACT: Meléndez himself indicated in 1797 that contemplation of the immensity, variety and order of the universe and its place in the great chain of being was one of the main subjects of his own philosophical poetry and a means

* Este trabajo se ha desarrollado en buena parte en el marco una de estancia en el Department of Hispanic Studies de la University of Sheffield, gracias a una Ayuda del Programa de Movilidad de Excelencia de la Universidad de Oviedo (2016). Debe mucho a las certeras apreciaciones de Philip Deacon y dos anónimos evaluadores; y no menos a la paciencia de Miguel Ángel Lama. 
of renewing Spanish poetry in general. The present study identifies this subject matter with the aesthetics of the cosmic sublime which characterizes a major strand of contemporary European philosophical poetry. In particular, the article highlights specific texts -in addition to ones from the European poets traditionally cited- which may have contributed to Meléndez's concept of the cosmic sublime, and draws attention to the presence of this thematic strand throughout Meléndez's poetic career (1780-1814), analyzing the chosen poems from the perspective of the literary, philosophical and religious context of the cosmic sublime.

Key words: Juan Meléndez Valdés; Philosophical Poetry; the Cosmic Sublime.

Cuando Meléndez Valdés publica por primera vez sus «poesías filosóficas y morales» en 1797, señala en el prólogo que estos poemas tratan de "las verdades sublimes de la Moral y de la Religión» y que sus principales asuntos son "la bondad de Dios, su benéfica providencia, el orden y armonía del Universo y la inmensa variedad de seres que lo pueblan y hermosean»; que tales temas "nos llevan poderosamente a la contemplación y a estimar la dignidad de nuestro ser y el encanto celestial de la virtud"; y que, si los buenos ingenios siguen esta senda, la poesía española se situará a la altura de la de poetas como Pope, Thomson, Young, Racine, Roucher, Saint-Lambert, Haller, Utz y Cramer, cuyas obras «son a un tiempo las delicias de los humanistas y filósofos» (OV, I: 67) ${ }^{1}$.

No resulta difícil reconocer a qué poemas se refería: en la oda X, Vanidad de las quejas del hombre contra su Hacedor, o en el discurso III, Orden del universo y cadena admirable de sus seres, la contemplación de la infinitud del universo y pluralidad de sus mundos y de la inmensa variedad de los seres que lo habitan dejan atónito a un contemplador que finalmente percibe en el aparente caos una armonía, un orden, una cadena, que lo conducen al reconocimiento de la existencia de un principio superior y terminan constituyéndose en prueba de una verdad de orden trascendental, eminentemente religiosa.

Leídos en serie y en contexto, tampoco es arriesgado reconocer en estos poemas que simbolizan la modernidad de la poesía filosófica europea uno de los modos preferidos de lo sublime dieciochesco, ese sublime cósmico que avanza sobre la noche estrellada neoplatónica estimulado por la argumentación newtoniana, los infinitos espacios revelados por la segunda revolución astronómica y las ordenaciones y cadenas diseñadas por la historia natural.

Por tanto, proponemos ahora volver a este corpus de poemas filosóficos dedicados a los "grandes asuntos» que el propio Meléndez sitúa en el eje de su poesía de "género más noble y elevado" (OV, I: 65), para perfilar ordenadamente

1. MelÉndez Valdés, Juan. Obras en verso (ed. Juan H. R. Polt y Jorge Demerson). Oviedo: Cátedra Feijoo. Centro de Estudios del Siglo XVIII, 2 vols., 1981 y 1983. Cito siempre por esta edición, abreviada como OV. 
sus tiempos y para analizarlos en el marco estético, filosófico y religioso de ese sublime cósmico europeo que deleitaba a «humanistas y filósofos». Hacerlo puede ser útil también en otros dos sentidos: para definir con más claridad cómo esta estética de lo sublime era identificada con la modernidad literaria -estar «a la altura de su siglo» en expresión de Quintana- ${ }^{2}$, y para aquilatar la conformación de la estética de lo sublime en España ${ }^{3}$.

\section{LO SUblime CÓSMiCO, SEGÚN ADDisOn: "A HEAVEN ADORNED WITH STARS AND METEORS»}

Aunque el término «sublime» invoca inmediatamente áridos desiertos, escarpadas montañas, altos precipicios y borrascosas tempestades -cualquier espacio signado por la grandeza y la amplitud en que la Naturaleza manifiesta todo su poder-, ya Joseph Addison incluía específicamente entre los escenarios que generaban tal sensación "a heaven adorned with stars and meteors» ${ }^{4}$. Hacia ese cielo tachonado de estrellas y meteoros habían mirado desde hacía siglos muchos poetas y sobre él reflexionarían varios tratadistas canónicos de lo sublime, pero importa ahora detenerse en los ensayos publicados en The Spectator porque, publicados en 1712, son los que sitúan los términos del debate sobre lo sublime cósmico en la Europa del siglo XVIII y los que modulan su mirada hacia la naturaleza y el cosmos; porque se percibe en ellos con claridad cómo se incardinan tempranamente de forma estable los distintos elementos de lo sublime cósmico; porque tenemos certeza de que

2. Manuel José Quintana afirma que «el poeta había levantado su ingenio a la altura de su siglo, y los objetos más grandes de la naturaleza, las verdades más augustas de la religión y de la moral eran el argumento de sus cantos» (Quintana, Manuel José. "Noticia histórica y literaria de Meléndez». En Meléndez Valdés, Juan. Poesías. Madrid: Imprenta Nacional, vol. I, 1820, pp. XV-LXIX; cit. en p. XLVII).

3. Sobre lo sublime en Meléndez Valdés contamos con los estudios de J. Mandrell y M. Raillard [MANDRELL, James. «The Literary Sublime in Spain: Meléndez Valdés and Espronceda». MLN, 1991, 106.2, pp. 294-313; "Lo sublime literario en la poesía española de los siglos XVIII y XIX: Meléndez Valdés y Espronceda". En CALDERA, Ermanno y Froldi, Rinaldo (eds.). Entresiglos 2. Roma: Bulzoni Editore, 1993, pp. 207-216; Raillard, Matthieu P. "Deism, the Sublime and the Formulation of Early Romanticism in Juan Meléndez Valdés and José de Cadalso". Studies in Eighteenth-Century Culture, 2010, 39, pp. 131-150]. Mandrell subraya al analizar brevemente lo sublime en La noche y la soledad que, "a pesar de su importancia en discusiones de literatura inglesa y francesa, la noción de lo sublime casi no ha entrado en consideraciones de literatura española” (pp. 213, 207). RAILLARD ha abundado en esta idea, señalando que "hispanists have generally shied away from any serious consideration of lo sublime». En su estudio analiza, a partir de la antología de John H. R. Polt y Georges Demerson (Poesías selectas. La lira de marfil. Madrid: Castalia, 1981), El invierno es el tiempo de la meditación, A la mañana, A la esperanza, La noche y la soledad, A Jovino, el melancólico, A la partida, El árbol caído, Después de una tempestad, La tempestad, La presencia de Dios y A la luna.

4. "[...] a troubled ocean, a heaven adorned with stars and meteors, or a spacious landscape cut out into rivers, woods, rocks, and meadows, the pleasure still grows upon us, as it arises from more than a single principle" (On the Pleasures of the Imagination, The Spectator, n. ${ }^{\circ} 412,23 / 6 / 1712$; remito a la edición de Donald F. Bond. London: Oxford University Press, 1965, tt. III y IV). 
Meléndez poseía estos ensayos ya en 1782, pues consta en el catálogo de su biblioteca: "Addison (Joseph), The Spectator, Londres, 1768, 3 vol. 8. ${ }^{\circ}$ (128 r.)"-mientras que no consta, por ejemplo, A Philosophical Enquiry into the Origin of our Ideas of the Sublime and Beautiful, de Edmund Burke-5; y porque en ellos se remite con frecuencia a Locke, cuya cosmovisión alienta en Addison y sabemos que marcó profundamente a Meléndez Valdés.

En On the Pleasures of the Imagination, Addison señala que son gratas y estimulantes a la imaginación las reflexiones de los autores de la "nueva filosofía" que contemplan la naturaleza, y detalla dos posibles modos de activar el efecto sublime, dos posibles miradas en perspectiva: hacia las alturas, para observar la multitud de planetas flotando y girando unos sobre otros y rodando en sus elipses con pompa y solemnidad, y vislumbrar los campos de éter que se extienden más allá de Saturno hacia el infinito y los océanos de luz; y hacia la tierra, admirando la variedad de especies hasta llegar escalonadamente a los seres diminutos, perfectos en sus minúsculas proporciones y en cuyo espíritu podrían existir otros tantos universos. Según Addison, el yo que intenta comprender permanece atónito ante especulación tal, que todo lo enlaza y proyecta ad infinitum, y ante la inmensidad, la solemnidad y la magnificencia del Universo ${ }^{6}$.

En otro ensayo al margen de la conocida serie, el propio Addison explicita que en ocasiones el contemplador atina con las leyes que ordenan el aparente caos, pero reconoce su incapacidad para aprehender su sentido último mediante la razón, lo que marca un giro «a lo divino». Señalando el retiro como un modo de fortalecer la fe, afirma que la propia creación es la mejor prueba de la existencia del Ser Supremo y, tras citar versos de los Salmos que argumentan que el firmamento proclama la gloria divina, concluye que «such a bold and sublime manner of Thinking furnishes very noble Matter for an Ode ${ }^{7}$. Para muestra, deja al lector una oda suya, que lograría notable difusión en el ámbito británico al ser convertida en himno entonado en la liturgia eclesiástica y utizarla Haydn como coro en The Creation (1798); y que es temprano testimonio poético de lo sublime cósmico del siglo XVIII europeo y de cómo lo sublime retórico clásico se está transformando en una categoría estética.

The Spacious Firmament on high,

With all the blue Etherial Sky,

And spangled Heav'ns, a Shining Frame,

Their great Original proclaim:

Th' unwearied Sun, from day to day,

Does his Creator's Pow'r display,

5. En adelante, todas las referencias al catálogo de la biblioteca proceden de Demerson, Georges. Don Juan Meléndez Valdés y su tiempo. Madrid: Taurus, 1971, t. I, pp. 119-139.

6. N. ${ }^{\circ} 420(2 / 7 / 1712)$

7. N. $465(23 / 8 / 1712)$ 
And publishes to every Land

The Work of an Almighty Hand.

Soon as the Evening Shades prevail,

The Moon takes up the wondrous Tale,

And nightly to the listning Earth

Repeats the Story of her Birth:

Whilst all the Stars that round her burn,

And all the Planets, in their turn,

Confirm the Tidings as they rowl,

And spread the Truth from Pole to Pole.

What though, in solemn Silence, all

Move round the dark terrestrial Ball?

What tho' nor real Voice nor Sound

Amid their radiant Orbs be found?

In Reason's Ear they all rejoice,

And utter forth a glorious Voice,

For ever singing, as they shine,

"The Hand that made us is Divine».

Por último, en un tercer ensayo sobre la «Scale of Beings», tras defender con Fontenelle la posible existencia de habitantes en otros mundos, Addison condensa con claridad los elementos de esta hipótesis científica en el marco estético de lo sublime cósmico: la sensación de maravilla que despierta la percepción de la gradación, perfección y variedad de los seres; la noción de que tanto la existencia de minúsculos seres como la variedad y multitud de especies y las imperceptibles transiciones entre unas y otras son muestra de la bondad y sabiduría del Ser Supremo; y la enunciación de la infinitud de la cadena, cuyas gradaciones han de ser superiores a lo que la vista permite conocer: las mismas que percibimos desde el insecto al hombre ha de haberlas, por analogía de la razón, en los seres que van desde el hombre a Dios ${ }^{8}$.

Cabe reseñar, además, que Addison cita en este ensayo en su favor extensamente el Essay Concerning Human Understanding, obra que en 1776 el propio Meléndez reconoce fundamental en su formación, al decirle a Jovellanos que "uno de los primeros libros que me pusieron en la mano, y aprendí de memoria, fue el de un inglés doctísimo. Al Ensayo sobre el entendimiento bumano debo y deberé toda mi vida lo poco que sepa discurrir». Se trata del capítulo sobre las innumerables especies de espíritus, en que Locke argumenta y ejemplifica cómo, si se atiende a la "serie de las cosas", paso a paso se perciben las «insensibles

8. $\quad$ N. ${ }^{\circ} 519(25 / 10 / 1712)$

9. Carta de 3/8/1776. Jovellanos, Gaspar Melchor de. Obras completas, t. II, Epistolario. Ed. J. M. Caso González. Oviedo: IFESXVIII, 1986, pp. 44-46; en adelante se citará: GMJ, OC, II. 
gradaciones» entre unos y otros y se advierte la conexión de todos los seres de los diversos reinos; lo que revela la armonía del universo y la grandiosidad del diseño de la Creación y, en última instancia, el infinito poder, sabiduría y bondad del Hacedor, el Arquitecto.

Por tanto, en 1712, y a la mano de Meléndez ya en 1782, tenemos una perfecta descripción de los mimbres que configuran lo sublime cósmico: el orden y grandiosidad del cosmos, la pluralidad de los mundos y la escala o cadena de los seres que todo lo une más allá de su diversidad; la idea de infinito se estructura en torno a la reformulación de la scala naturae y de la neoplatónica noción del sistema de la naturaleza como una "cadena del ser», que terminó siendo la "fórmula sagrada del siglo», en feliz sintagma de Arthur Lovejoy ${ }^{10}$; y que constituye una verdadera "estética del infinito", en no menos acertada expresión de Marjorie Hope Nicolson ${ }^{11}$

Y también ya el giro a lo divino de lo sublime cósmico, que, en el fondo, remite al viejo argumento cosmológico de la existencia de Dios, la prueba físicoteológica que a Kant merecía respeto, aunque no certeza. Como señala Ernest Tuveson en su ensayo sobre lo sublime y la divinidad, los objetos sublimes eran concebidos como "images of God's being constantly before human eyes»" Así, la grandeza de lo natural sublime se vierte hacia lo divino y termina siendo emblema y manifestación de la grandeza del creador y prueba de su necesaria existencia. En estos términos condensa la operación David B. Morris en The Religious Sublime:

Newton in effect deified the concept of immensity by calling space the vast sensorium of God. The empty interstellar reaches, which had terrified Pascal with thoughts of nothingness, could be comfortingly addressed by Addison as evidence of God's stupendous handiwork, and the notion of the universe as sublime but explicable artefact blended easily with the physico-theological doctrine of fitness: from the wheeling of the planets to the operation of the bladder [...] the created universe was held to show a world instinct with purpose. Thus, even the wildest and apparently most irregular aspects of nature, which earlier ages had shunned, could be explained as part of the divine economy and appreciated as revelations of God's power and wisdom. Certainly, the new enthusiasm for scientific and rationalistic explanations of the natural world helped to support the doctrine of fitness, but perhaps an additional reason for its popularity was its usefulness in filling the void created by Locke's rejection of innate ideas. Unable to argue that man is born

10. Lovejoy, Arthur O. The Great Chain of Being. Cambridge: Harvard University Press, 1936; La gran cadena del ser. Historia de una idea. Barcelona: Icaria, 1983, p. 234.

11. NiCOLSOn, Marjorie Hope. Mountain Gloom and Mountain Glory: The Development of the Aesthetics of the Infinite. Ithaca, NY: Cornell University Press, 1959

12. Tuveson, Ernest. "Space, deity and the "natural sublime".. Modern Language Quarterly, 1951, 12.1, pp. 13-19. 
with a knowledge of God, eighteenth-century thinkers increasingly sought to derive assurances of God's existence from human experience ${ }^{13}$.

Esto es lo sublime cósmico según Addison ya en 1712; pero la estabilidad de lo sublime cósmico y sus elementos axiales a lo largo del siglo ilustrado se percibe al contrastar sus reflexiones con la Oración sobre el estudio de las Ciencias Naturales que Jovellanos lee en el Real Instituto de Náutica y Mineralogía de Gijón en $1799^{14}$, donde además se palpa la plena asimilación de lo sublime cósmico en España.

Para eficaz legitimación de la nueva disciplina implantada, Jovellanos enumera ante los alumnos los provechos que se siguen del estudio de la Naturaleza; los invita a recorrerla observando desde la inmensidad de los cielos hasta la variedad e infinitud de entes que pueblan la tierra; y los exhorta a vislumbrar sus leyes y reconocer el orden que se oculta tras el aparente caos. El argumento final es que conocer la Naturaleza supone comprender el cosmos y, en última instancia, descifrar el sentido de la existencia y reconocer la de un Ser Supremo, artífice de tal construcción.

Los elementos que conforman lo sublime cósmico siguen siendo: un sujeto que observa el universo "extasiado en la contemplación de tan admirable armonía»; la inmensidad del universo: "admirable», «inmenso", "sublime», "espectáculo augusto»; el absoluto poder de la Naturaleza: «Engendre o destruya, ¡cuán portentosa es su fuerza!, o ya de un grano menudísimo haga brotar el roble, o ya devore y convierta en sustancia propia animales y plantas, mármoles y bronces, palacios y templos, y todo cuanto existe»; la variedad de los seres, "desde la enorme ballena que sondea los mares del Norte o se tiende sobre sus espaldas como una isla abatida en vano de las ondas» hasta la «inmóvil lapa, que nace y muere pegada a nuestras peñas»; el nexo que pese a todo ordena el universo: «qué escala de perfección tan maravillosa!»; «el admirable y portentoso lazo con que sostiene el universo, atando y subordinando todos los seres", "ordenándolos para la conservación del todo"; y, finalmente, el reconocimiento del "gran fin", "Ser supremo", "Ser de los seres", "Ser infinito".

En todo caso, dicha estabilidad no ha de hacernos perder de vista que lo sublime cósmico -como lo sublime- trasciende los tiempos y muta con ellos: pulula por la poesía filosófica europea desde el poema de Addison de 1712 hasta bien entrado el siglo XIX -todavía en 1828 Blanco White interrogaría en el tan antologado Night and death refiriéndose a Adán: "Did he not tremble for this lovely frame

13. MORrIS, David B. The Religious Sublime: Christian Poetry and Critical Tradition in 18thCentury England. Lexington: The University Press of Kentucky, 1972. Ha de verse, especialmente, "Poetic Practice: varieties of the Religious Sublime. Imaginative devotion: Addison, Thomson, Young", pp. $131-154$.

14. Jovellanos, G. M. Obras completas, t. XIII, Escritos pedagógicos. Ed. Olegario Negrín Fajardo. Oviedo: IFESXVIII, 2010, pp. 403-421. 
/ this glorious canopy of light and blue?»-15; pero todo se va matizando: cuando Meléndez firma el prólogo de su última edición, en 1815, Coleridge ya le escribe a Wordsworth: "Whatever in Lucretius is Poetry is not philosophical, whatever is philosophical is not Poetry» ${ }^{16}$.

\section{Más Allá de AdDison: Fuentes y CONTEXTOS De lO SUblime CósMico EN MELÉNDEZ}

Hemos fijado el concepto de lo sublime cósmico a partir de los ensayos de Addison por ser los que tempranamente sitúan los términos de las reflexiones sobre este asunto en el siglo XVIII, pero esto no implica que Addison fuera la fuente única ni primordial de Meléndez Valdés. Así lo demuestran las fuentes claramente identificadas de buena parte de sus poemas filosóficos ${ }^{17}$; y tal hace pensar la

15. Blanco White, José María. Obra poética completa. Ed. Antonio Garnica y Jesús Díaz García. Madrid: Visor, 1994, p. 348.

16. Gale, Monica R. (ed.). Oxford Readings in Classical Studies. Lucretius. Oxford: Oxford University Press, 2007, p. 2.

17. Los pioneros estudios en que Peers (1926), Colford (1942), Demerson (1961; trad. 1971), EFFross (1966), GLENDINNING (1968, pero 1966) y ForCione (1966) rastrearon la influencia de la poesía europea en la poesía de Meléndez configuraron un mapa que en lo sustancial permanece estable, asentado gracias a la edición crítica de la poesía completa de Meléndez realizada por Polt y Demerson. Peers, Colford y Demerson señalan la influencia de Milton en La caída de Luzbel; Peers y Colford señalan la influencia de Young en La noche y la soledad; Peers también apunta, sin desarrollarla, su influencia en la elegía A Jovino. El melancólico, y en las odas El invierno es el tiempo de la meditación, La presencia de Dios, Al ser incomprehensible de Dios y Vanidad de las quejas sobre su Hacedor; Demerson localiza pasajes de la versión de Le Tourneur en el plan de la Oda a la muerte de su hermano; Glendinning coincide en esta influencia, y suma la que percibe en la oda Vanidad de las quejas del hombre contra su Hacedor, en la oda VI Al ser omnicomprensible de Dios y, matizada por Cadalso, en la Canción de un infeliz que sin haber dormido toda la noche se queja del vecino día. Colford apunta la influencia de Pope en Vanidad, luego recogida por Demerson, Effross y Forcione, que analiza en profundidad las correspondencias entre ambos poemas. En cuanto a Thomson, Colford y Glendinning señalan -con maticeslos notables ecos de Winter en El invierno es el tiempo de la meditación; y Demerson reconoce el influjo de Summer en Los segadores, mientras que Glendining señala el influjo de Autumn en este poema.

Véase PeErs, E. Allison. "Milton in Spain". Studies in Philology, 1926, 23.2, pp. 169-183; PEers, E. Allison. "The Influence of Young and Gray in Spain". Modern Language Review, 1926, 21.4, pp. $404-418$. COlford, William E. Juan Meléndez Valdés: a Study in the Transition from Neoclassicism to Romanticism in Spanish Poetry. Nueva York: Hispanic Institute, 1942. Demerson, G. Don Juan Meléndez Valdés y su tiempo. Madrid: Taurus, 1971, 2 vols. (pero en la versión francesa en 1961); GLENDINNING, Nigel. "Influencia de la literatura inglesa en España en el siglo XVIII. En La literatura española del siglo XVIII y sus fuentes extranjeras. Oviedo: Cátedra Feijoo, 1968, pp. 47-93 (pero leída en 1966). EFFross, Susi Hilburn. "The influence of Alexander Pope in Eighteenth-Century Spain». Studies in Philology, 1966, 63, pp. 78-92; Forcione, Alban. "Meléndez Valdés and the Essay on Man». Hispanic Review, 1966, 34.4, pp. 291-306. Un completo rastreo de fuentes poéticas puede seguirse también en la tesis de Kenwood (KeNWOOD, Alun. A study of nature in some Spanish pre-romantic poets, with special reference to sources. Presented for the degree of Master of Arts at the University of Sheffield: 1966). En esta cuestión se ha profundizado en trabajos más recientes, como los de GARCía CALDERón, Ángeles. "La poesía inglesa de 
notable cultura poética que ha de suponerse al que fuera sustituto de la Cátedra de Humanidades de Salamanca desde 1778 y catedrático desde $1781^{18}$, que incluso pensó en cotejar los principios de las cuatro poéticas de Aristóteles, Horacio, Vida y Despréaux editadas por Batteux ${ }^{19}$.

Por ello, antes de abordar la lectura de la poesía filosófica de Meléndez, y aun a riesgo de merecer el certero dardo de Pedro Salinas contra la crítica bidráulica y la obsesión por las fuentes ${ }^{20}$, conviene volver la vista a su epistolario, al catálogo de su biblioteca de 1782 y a los prólogos de sus ediciones. El rastreo revela la presencia de un amplio corpus fuertemente marcado por la impronta de lo sublime cósmico, en cuya lectura pudo el poeta formar su gusto por este asunto, más allá del Paradise Lost de John Milton, The Seasons de James Thomson, el Essay on Man de Alexander Pope y los Night Thoughts de Edward Young, que obviaremos aquí por muy transitados.

El fragmentario epistolario conservado con Jovellanos de la etapa de 17761779 aporta datos especialmente sustanciales ${ }^{21}$. Así, dos cartas de agosto de 1776 ponen sobre la mesa tres textos de interés. Por un lado, en la de 3 de agosto ya citada $^{22}$ manifestaba su reconocimiento hacia el Ensayo sobre el entendimiento bumano -consta en la biblioteca: "Essai philosophique concernant l'entendement bumain... (trad. par M. Coste), Amsterdam, 1774, 4 vol. in 12 (74 r.)»-. En el libro II del ensayo de Locke, que versa sobre lo infinito, Meléndez aprehendería ya

la Naturaleza en el siglo XVIII y su influencia en Meléndez Valdés». Revista de Literatura, 2007, 138, pp. 519-541; "Salomon Gessner y su influencia en Meléndez Valdés a través de Thomson». Futhark: Revista de Investigación y Cultura, 2007, 2, pp. 131-147; «El ascendiente de Thomson y Saint-Lambert en los romances rurales de Meléndez Valdés». Hikma, Estudios de Traducción, 2011, 10, pp. 9-27.

18. Demerson, Don Juan Meléndez Valdés y su tiempo, t. I, pp. 62-64.

19. Susi H. Effross señala que quiso comparar las de Aristóteles, Horacio y Pope (EFrross, Susi Hilburn. "The influence of Alexander Pope in Eighteenth-Century Spain», p. 81). Pero la referencia en las cartas a Jovellanos de 14/9/1778 y 16/1/1779 es clara: "Yo había pensado hacer una comparación de las cuatro poéticas principales, de Aristóteles, Horacio, Vida y Despréaux, metiéndome también con el Ensayo sobre la crítica de Pope y nuestro Ejemplar poético de Juan de la Cueva, comparando las reglas de todos con las del filósofo [Aristóteles] y entre sí, y haciendo un examen crítico de ellas, distinguiendo las fundamentales e invariables de las arbitrarias o de convención"; "Quisiera hablar largamente con V.S. sobre el acto que tengo pensado defender de Humanidades, que es nada menos que las cuatro poéticas de M. Batteux y algunas otras cosas» (GMJ, OC, II: pp. 139-140; 152).

20. SAlinas, Pedro. Jorge Manrique, o tradición y originalidad. Buenos Aires: Editorial Sudamericana, 1947, pp. 115-117. También es de interés su obra Ella y sus fuentes. En Teatro completo. Sevilla: Alfar, 1992.

21. Sustanciales, pero no definitivos; siguiendo el contenido de la serie conservada, se hace evidente que está incompleta y lo que conocemos de varias de estas cartas no son más que fragmentos de los originales seleccionados por Cueto (BAE, 61). Caso González señalaba que los originales debieron de estar entre los papeles del marqués del Pidal y pasaron a Martín Fernández de Navarrete, por lo que deberían estar en el palacio de Ábalos del marqués de Legarda, al que no tuvo acceso en 1985 (G. M. J, OC, II: p. 41) y tampoco Emilio Palacios (Meléndez VAldés, Juan. Obras completas. Ed. Emilio Palacios Fernández. Madrid: Biblioteca Castro, 1997, t. III, pp. 315-419).

22. GMJ, OC, II: pp. 44-46. 
que esa idea de omnipotencia, sabiduría y bondad de Dios no es innata, sino que procede de la experiencia de los sentidos, de la percepción de esas cualidades sublimes de inmensidad en la naturaleza ${ }^{23}$.

Y en esta misma carta, señala que ya ha traducido hasta 300 versos de la Ilíada, labor en la que se empecina entre 1777 y $1778^{24}$, aunque el 6 de octubre de 1777 confiese a Jovellanos su incapacidad y finalmente no aplicara a sus "dorados labios la sonante trompa", como le proponía el asturiano en la didáctica. Dicho trabajo hubo de familiarizarlo con la estética de lo sublime divino; ya Longino ejemplificaba que lo sublime es cualidad estética de los dioses, que crean y dominan, citando como ejemplo de sublimidad extrema el fiat lux del Génesis y los versos sobre Poseidón en la Ilíada: "Temblaron las altas montañas y los bosques y las cumbres [...]. Sobre las olas guió él su carro y a su alrededor saltaban alegremente por todas partes monstruos de las profundidades; ellos reconocían a su señor ${ }^{25}$.

Por otro lado, en la de 24 de agosto de 1776, Meléndez señala que algunas ideas de La reflexión de Trigueros ya las ha visto «en una de las Noches del doctor Young. Pero en medio de todo esto, la moral y las doctrinas son excelentes, y reina en toda la pieza un aire magistral y mil hermosuras y salidas poéticas y llenas de calor y de genio» ${ }^{26}$. El poeta filósofo seguía más de cerca a Pope y Addison ${ }^{27}$,

23. Locke, John. Ensayo sobre el entendimiento humano. Trad. de E. O’Gorman, pról. de José A. Robles y Carmen Silva. México: Fondo de Cultura Económica, 1999.

24. "Excitado de lo que V.S. me dice, he emprendido algunos ensayos en la traducción de la inmortal Ilíada, y ya antes alguna vez había probado esto mismo; pero conocí siempre lo poco que puedo adelantar [...]" (3/8/1776; GMJ, OC, II: p. 45); "Me reservo esto y el asunto de Homero para cuando vuelva a esta ciudad" (14/4/1777; GMJ, OC, II: p. 56); "Correrías para entrarme en el santuario de la Ilíada" (6/10/1777; GMJ, OC, II: p. 95); "V.S. me dirá que para qué me he traído la Ilíada, ni nombro a Homero, no haciendo nada de provecho ni cumpliendo mi palabra dada. [...] Esta traducción pide una aplicación cuasi continua y una lección asidua de Homero, para coger, si es posible, su espíritu. Yo, embebido en el original, acaso haré algo» (26/6/1778; GMJ, OC, II: p. 131).

25. Longino. Sobre lo sublime. Ed. José García López. Madrid: Gredos, 1996, p. 162.

26. GMJ, OC, II: p. 49.

27. Así lo reconocía Trigueros y también la temprana crítica, para bien y para mal: según Cavanilles «ha imitado el estilo de Pope y Addison, y su semejanza a estos dos grandes hombres es su mayor elogio"; según Custodio: "Sé bien que tiene el Ensayo de Pope en cinco lenguas, que apenas lo deja de la mano y que, desde el principio de su primer poema lo imita, lo sigue, abraza sus ideas» (AGUILAR PIÑAL, Francisco. Un escritor ilustrado: Cándido María Trigueros. Madrid: CSIC, 1987, pp. 81, 147). Sobre esta obra ha de consultarse también Aguilar PiÑal, Francisco. "La poesía filosófica de Cándido María Trigueros". Revista de Literatura, 1981, 43, pp. 19-36; ABELLÁN, José Luis. "La poesía filosófica: un capítulo de la historia de las ideas del siglo XviII. En Homenaje a Juan López-Morillas. De Cadalso a Aleixandre: Estudios sobre literatura e historia intelectual españolas. Ed. J. Amor y Vázquez y A. David Kossoff. Madrid: Castalia, 1982, pp. 21-39. Rico GARCíA, José Manuel. "Construcción y sentido de El viaje al cielo del poeta filósofo de Cándido María Trigueros». En Actas del XIV Congreso de la AIH. Newark: Juan de la Cuesta, 2004, vol. III, pp. 459-467. 
pero Meléndez aún no conoce el Essay on Man, que Jovellanos envía a Batilo y Delio en otoño, después de otra "remesa de las poesías filosóficas» de octubre ${ }^{28}$.

Cabe pensar que La reflexión ${ }^{29}$ modelara también su conocimiento de lo sublime cósmico, pues Trigueros concibe la armonía de la naturaleza según los parámetros sublimes de la gran cadena del ser y describe el espacio conforme a la mecánica newtoniana y la ley de gravitación universal: "Con atracción secreta, que al Cielo allí ha grabado / un cuerpo hacia otro cuerpo sin cesar es llamado, / y cada cuerpo a todos, y todos a su centro: / una atracción externa fomenta la de adentro: / Systemas a Systemas atraen atraídos, / y a su general centro son todos convertidos». Aquí se hallaba también ya la imagen del yo poético que "sobre un extremo tan alto colocado» contempla en perspectiva el espectáculo de «el milagro estupendo del sistema mundano"; ante tal visión, siente empequeñecerse su mundo - "la enorme Mole que Tierra hemos nombrado / [...] quedaba sumergida, y envuelta entre la Nada / de la masa invisible de donde fue formadan-; cuestiona el lugar que ocupa en tal espacio el propio ser humano - «un Insecto, a quien dicen el Hombre, en ella había / que es, comparado a ella, cual de la arena un grano / respecto de la masa del muy ancho Oceano [sic]»- y se sorprende de que "este insecto frágil, que vive una mañana / capaz ser pueda acaso de la soberbia vana / que dentro de mí noto cuando no estoy atento / al Grande que me hizo con sólo un breve acento»; y concluye: "Ah, decía en mí mismo su ser reflexionando / ¡cuán grande es el inmenso Señor que voy buscando! / Yo para con la Tierra, la Tierra para el Orbe / es cual gota invisible que el agua del mar sorbe; / mas todo el universo para su Dios ha sido / menos que ante el sol fuera ni un átomo lucido».

El poeta filósofo insiste -de manera un tanto deslavazada, todo hay que decirlo- en que el único modo de concebir al «ser» sería alcanzar "con muy perfecto modo / la magnitud inmensa del universo todo. / Mas todo el universo mayor es que tu idea», así que anima al lector a contemplar el cosmos: "Por el campo del éter tu reflexión pasea, / lanza largas miradas por rumbos insondables, / mira en él, cual nadando, soles innumerables / que a innumerables Tierras atraen e iluminan. / Ve que en torno perpetuo mil círculos terminan / concéntricos, o siguen elipses muy disformes, / que en su rumbo arreglados, precisos y uniformes, / forman indefinidos sistemas peculiares. / Todos, cuando con pasmo y atento lo repares, / parecerán inmensos, grandes, incomprensibles; / mas son como pequeñas astillas invisibles, / si de sistemas tantos, con sistema diverso, / formas el gran sistema de todo el universo".

28. Dice Diego Tadeo González a Jovellanos: «Recibo la de V.S. con el Pope, que leeré tantas veces cuantas basten para tomarlo de memoria, meditar mucho sus bellezas, seguirle el genio y revestirme de su espíritu» (3/11/1776; GMJ, OC, II: pp. 52-53). Se trataba de tomarlo como modelo para el poema Las edades. Días antes había señalado: "Uno y otro damos a V.S. repetidas gracias por la remesa de las poesías filosóficas» (8/10/1776; GMJ, OC, II: pp. 51-52).

29. Trigueros, Cándido María. El poeta filósofo, o poesías filosóficas en verso pentámetro. Sevilla: Manuel Nicolás Vázquez, 1774-1778. 
Además, el 24 de mayo de 1777 Meléndez le señala a Jovellanos que tuvo noticia por la Vida de Clemente XIV del marqués de Caracciolo de "que el prelado Stays [sic] es conocido por sus dos poemas del cartesianismo y el neutonianismo, que se reputan superiores al Anti-Lucrecion y que, habiendo leído este poema de Polignac, desea tener noticia de estos otros poemas. Emerge así el corpus que orbita alrededor del De rerum natura y que toma al poema clásico como modelo estético, aunque fuera para refutar su ateísmo. No en vano, Jovellanos hablará de los progresos literarios de Batilo en estos términos: el "feliz imitador de Anacreonte y Villegas, podrá imitar algún día a Lucrecio y el amigo de Bolingbroke [Pope] con igual gloria ${ }^{30}$.

Meléndez poseía el poema filosófico de referencia de la Antigüedad recuperado por el Renacimiento -consta en catálogo de 1782: «Lucrèce, Lucretii Cari de rerum, natura cum notis Thomae Creech, Londini, 1754, 1 vol. in $8 .^{\circ}$ (31 r.)»- ${ }^{31}$; conocía el Anti-Lucretius, que versa, como el propio título indica, sive de Deo et natura, y funciona como buque insignia de la reacción frente al ateísmo del pagano que negaba la creación ex nibilo, la providencia y la inmortalidad ${ }^{32}$; y dio con la segunda edición del poema épico de Benedicto Stay -no Gérotée Stay- ${ }^{33}$, pues figura en el catálogo de 1782: "Stay (Benoît), Benedicti Stay philosophiae versibus traditi [sic] libri VI, Romae, 1747, 1 vol. in $8 .^{\circ}$ (40 r.)». En esta segunda versión, en que se añaden los descubrimientos de Galileo, Kepler y Newton, habría leído en verso tópicos habituales de la poesía filosófica de corte científico y de lo sublime cósmico: las teorías sobre la pluralidad de los mundos, la teoría newtoniana

30. Jovellanos, G. M. Obras completas, t. IX, Escritos asturianos. Ed. Elena de Lorenzo y Álvaro Ruiz de la Peña. Oviedo: IFESXVIII, 2005, p. 10. Diego Tadeo González le dirá a Jovellanos en 1777: "Tampoco hallo yo gusto alguno en leer a Lucrecio» (GMJ, OC, II: pp. 103-104), de donde se desprende que algo había que a Jovellanos no le convencía.

31. Según Anne Janowitz, "the context within which Lucretius's sublimity came to influence eighteenth century ideas about the shape of the cosmos was certainly through Joseph Addison, who drew on languages of both aesthetics and Newton's Christian providentialism to present a discussion of the cosmic sublime» [Janowitz, Anne. "Sublime». En A Handbook of Romanticism Studies. Ed. Joel Faflak y Julia M. Wright. Chichester (Reino Unido): John Wiley \& Sons, 2012, pp. 55-67; cita en pp. 58-59]. Sobre Lucrecio y lo sublime en la Antigüedad, véase PORTER, James E. "Lucretius and the Sublime». En The Cambridge Companion to Lucretius. Cambridge: Cambridge University Press, 2007, pp. 172-174; PORTER, James E. The Sublime in Antiquity. Cambridge: Cambridge University Press, 2016. Para las imágenes del De rerum natura en Virgilio, Horacio y Milton, véase HaRDIE, Philip. Lucretian Receptions. History, the Sublime, Knowledge. Cambridge: Cambridge University Press, 2009.

32. No figura la obra de Polignac en el catálogo, pero ya estaba incorporado en ese mapa parcial de lecturas de Meléndez que Demerson trazó para el período de 1772-1780 (Don Juan Meléndez Valdés y su tiempo, t. I, pp. 106-111).

33. Caso González identificaba erróneamente a Stay con el obispo de Edesa Gérotée Stay (GMJ, OC, II: 61, nota 8). La información sobre las dos versiones del poema, Philosophiae versibus traditae libri (Venecia, 1744, reed. 1747; Roma, 1755, 1760 y 1792), procede de HaskELL, Yasmin. "Breaking ground: scientific poetry in Enlightenment Rome». En Loyola's Bees: Ideology and Industry in Jesuit Latin Didactic Poetry. New York: Oxford University Press for the British Academy, 2003, pp. 178-244. 
de la gravedad, las teorías de Huygens o las leyes del movimiento planetario de Kepler, cuya visión cosmológica se fundaba en la armonía pitagórica de las esferas celestes y se orientaba hacia la celebración de la existencia y sabiduría divinas. Dispusiera Dios los planetas en poliedros, círculos o elipses, para Kepler estaban ordenados y por él lo habían sido, como Stay quiere resaltar. Estos poemas eran de referencia entre la poesía jesuítica didáctica: de hecho, un poeta como Roberti, reconociéndose seguidor de Lucrecio y Stay, preguntará: «Por qué no pueden algunos poetas convertirse en filósofos con sus versos, si algunos filósofos se han convertido en poetas con sus sistemas? ${ }^{34}$.

El 6 de octubre de 1777 Meléndez señala a Jovellanos que están pedidas las Estaciones de Saint-Lambert, que ha acabado de leer el Poema de la religión de Racine - "me ha gustado infinito y he animado a nuestro Delio a su traducción»-, que disfruta con la Teodicea de Leibnitz y el Metastasio - «estoy embelesado con ellos»- y que ha "empezado a poner en verso» los Versos dorados de Pitágoras ${ }^{35}$.

Testimonia el catálogo de la biblioteca que Meléndez manejaba los Commentaires des vers dorés de Pythagore de Hierocles editados en $1742^{36}$, síntesis en verso de la filosofía pitagórica difundida por el neoplatonismo ${ }^{37}$. En el pequeño breviario encontraría perfilada la noción de la divinidad como una unidad de que dimana la causa de todo lo existente, que es digno reflejo del creador, y en los comentarios de Hierocles un intento pionero de armonización de la tradición religiosa griega con el cristianismo.

También consta en el catálogo que Meléndez manejaba la edición publicada en Lausanne en 1770 de los Essais de Theodicée sur la bontée de Dieu, la liberté de l'homme et l'origine du mal (1710), que buscan una justificación racional de la existencia de Dios y constituyen la respuesta filosófica dieciochesca de referencia al debate sobre si la existencia del mal cuestiona la existencia de Dios: en lo que hace a lo sublime cósmico, se defiende aquí la posibilidad de una comprensión holística del mundo y se concibe una armonía ordenada por Dios y accesible a la razón humana, resistiéndose a admitir el absurdo y el $\operatorname{caos}^{38}$.

Y poseía la edición de 1773 del antilucreciano La religion, poème (1742) en que Louis Racine ensaya una justificación racional de la religión. Según la muy

34. "Ma io, che amo Lucrezio e Stay, sono contento d'interrogare: Urania, che è una filosofessa, no è ella una musa? E perchè non potranno parecchi poeti co'loro versi divenir filosofi, si parechi filosofi son devenuti co'lor sistema poeti?» (Loyola's Bees, p. 185).

35. GMJ, OC, II: p. 95.

36. Demerson, Georges. Don Juan Meléndez Valdés y su tiempo, t. II, p. 128.

37. La presencia del neoplatonismo en la poesía erótico-pastoril ha sido contrastada por Rodríguez de la Flor, que la analiza en La hermosura del alma jamás se acaba y es la mejor belleza (RODRÍGUEZ DE LA FloR, Fernando. "La filiación neoplatónica de un poema de Meléndez Valdés». Dieciocho, 1980, 3.1, pp. 51-61).

38. GiACOMONI, Paola. Il laboratorio della natura: paesaggio montano e sublime naturale in età moderna. Milán: Franco Angeli, 2011, p. 11. Véase también: RuTHERFORD, Donald. Leibniz and the Rational Order of Nature. Cambridge: Cambridge University Press, 1995. 
difundida traducción de Ranz Romanillos, encontramos versificados en clave de lo cósmico sublime los descubrimientos de Newton, que ve "cómo en un vacío dilatado / todos los cuerpos sin cesar se mueven. / Un recíproco imperio ejercitado / siendo de uno en el otro, uno a otro inclina / a que su misma dirección conserve: / hasta que a un mismo peso al fin rendidos / no hallándose ninguno que no observe / las mismas leyes, todos se conmueven, / buscando un común centro entre sí unidos. / ¿Quién podrá entre estos cuerpos desiguales / de sus fuerzas centrales / describir los combates tan reñidos?». En términos cósmicos similares se describen los hallazgos de Galileo: "Los círculos, los cielos y cristales. Todo queda mudado: da imperioso / Galileo un decreto nunca oído, y en fin lejos destierra / la tierra de sus puntos centrales. / El sol ya sosegado presidiendo / al día con quietud y el centro siendo / de todo el Universo rodeado / ve que es del cielo y de la misma tierra». Y el ensalzamiento de Réaumur subraya la existencia de los invisibles insectos omnipresentes en la cadena del ser: «iCuántos habitadores ignorados / de un mundo hasta hoy oculto, de la nada / por ti, Reaumur ilustre, son sacados! / En el silencio un pueblo sumergido, / y sin espectadores, ¿cómo puede / sufrir que tanta pompa oculta quede? / Mas si de un vidrio vil no es ayudada, / mirarlo piensa nuestra vista en vano" ${ }^{39}$.

Por último, es de interés la carta a Ramón Cáseda de marzo de 1782 en que, con motivo de la muerte de Cadalso, señala que ha comenzado una canción fúnebre e indica que Dalmiro «fue el primero que sublimó nuestros tiernos ojos hasta los cielos y nos hizo ver en ellos las inmensas grandezas de la creación ${ }^{40}$.

Al margen del epistolario, hallamos en el catálogo de la biblioteca de 1782 otras fuentes que también se mueven en el ámbito de lo sublime cósmico. Reordenadas cronológicamente, consta una edición de los Pensées de M. Pascal sur la religion et sur quelques autres sujets (1670), obra en defensa del cristianismo contra ateos y escépticos, cuya influencia en la oda X Vanidad de las quejas del hombre contra su bacedor fue analizada muy brevemente por Gilbert M. Fess: "The purpose of the Spanish poem is the same as that of the Pensées, to give man a just estimate of his position in the universe, to show him both his insignificance and his greatness, and to lead him thereby to an attitude of resignation and piety ${ }^{41}$.

También que tenía las Oeuvres complètes (París, 1769) de Fontenelle, donde estarían los Entretiens sur la pluralité des mondes (1686), con sus vórtices cartesianos, torbellinos de éter, innumerables sistemas solares y mundos probablemente habitados, y también el célebre elogio de Newton.

Y varios clásicos de la literatura apologética del cristianismo en clave científica de principios de siglo, como los cinco volúmenes de $A$ demonstration of the

39. Madrid: Imprenta Real, 1786, pp. 227 y ss.

40. Meléndez VAldés, Juan. Obras completas. Ed. Emilio Palacios Fernández, t. III, pp. 394-395.

41. FEss, G. M. "Meléndez Valdés' Vanidad de las quejas del hombre contra su hacedor and the Pensées of Pascal». Modern Language Notes, 1924, XXXIX, pp. 282-284. 
being and attributes of God from bis acts of creation (Dublín, 1751), valorados en unos nada despreciables 205 reales, que además Meléndez posee por partida doble, pues también consta la traducción de Ricotier (1744). La célebre Boyle Lecture del año 1704, defendida en ocho sermones en la catedral de San Pablo por el que pronto sería nombrado capellán de la reina Ana, comparte los principios de este foro del círculo newtoniano, orientado a probar la verdad de la teología cristiana y a reflexionar sobre las relaciones entre la filosofía natural y la religión. Como indica Samuel Clarke en el subtítulo, la Lecture está concebida «in answer to Mr. Hobbes, Spinoza and their followers", como demostración de que determinados hechos científicos necesitan de la existencia e intervención divinas ${ }^{42}$.

Consta también "Nieuwentyt, L'existence de Dieu démontrée par les merveilles de la nature, París, 1725, 1 vol. in $4 .^{\circ}$ (60 r.)", traducción del original holandés de 1715. Aunque su título no necesita de mucha más explicación, el de la traducción inglesa explicita su finalidad con más claridad: The Religious philosopher, or the Right use of contemplating the works of the Creator, designed for the conviction of atheists and infidels (1718); además, aclara el subtítulo que atiende a "the wonderful structure of animal bodies, in particular man", "the no less wonderful and wise formation of the elements and their various effects upon animal and vegetable bodies" $y$, finalmente, "the most amazing structure of the heavens, with all its furniture».

Obviamente, Bernard Nieuwentyt sostiene que la naturaleza -y toda esa maravilla y asombro que en el título se invocan- es prueba de la existencia de la divinidad y que la observación científica del mundo natural demuestra la sabiduría y bondad divinas. En la introducción de la edición que maneja Meléndez se condensa así su asunto: "Notre sçavant auteur a ramassé toutes les nouvelles découvertes que d'autres ont faites sur les oeuvres de la Nature, \& toutes celles qu'il a faites lui-même; \& il conclut de chacune en particulier, qu'elles manifestent un Auteur toutpuissant, souverainement sage, infiniment bon, qui a créé le mond, \& tout les êtres pour de certaines fins, \& qu'ils répondent tous parfaitement bien aux fins pour lesquelles il les a créez " ${ }^{43}$.

A capítulos introductorios como "La Toute-présence éternelle de Dieu prouvée par les Créatures", siguen asuntos científicos tan variados como "L'usage des intestins", "De la nature de l'air dans les tems de peste», "Représentation grossiere de la circulation du sang", "La réfraction des rayons", "Le crystallin est un microscope» o, centrándonos en aspectos relacionados con lo sublime cósmico, capítulos como «Un pouce cubique de matiere contient un million de particules visibles» $\mathrm{O}$ «Une goute d'eau se peut diviser en plus de 26000000 parties» -hipótesis que funda

42. Clarke, Samuel. A Demonstration of the Being and Attributes of God and Other Writings, ed. Ezio Vailati. Cambridge: Cambridge University Press, 1998. Véase también: Lovejoy. The Great Chain of Being: A Study of the History of an Idea, pp. 149-151.

43. Paris: J. Vincent, 1725. Las citas en pp. IV y 479. 
en las observaciones de A. Leuwenhoeck- $\mathrm{O}$ «De la grandeur immense des étoiles fixes», donde argumentará, como suele:

Incrédules, qui doutez encore de la puissance \& de la sagesse d'un Dieu, levez vos yeux au Ciel; supposez que c'est pour la premiere fois que vous voiez les Cieux ornez de tant d'astres brillans, \& dites-nous si vous n'êtes pas convaincus que ce sont-là les ouvrages d'un Créateur tout-puissant, \& que ce n'est pas le hazard qui leur a donné l'éxistence \& l'éclat dont ils frappent vos yeux? Une sphére vous paroît arrangée par un Ouvrier. Que direz-vous donc des Cieux, sur tout si vous jettez les yeux sur leur étenduë immense?

La obra concluye, a lo divino, con artículos como «Le premier mouvement prouve l'Existence d'un Dieu de même que la continuation \& la communication du mouvement", "Preuves de l'Existence d'un Dieu tirées du mouvement des particules de la lumiere» o "L'Existence de Dieu prouvée par les Loix du Méchanisme en general».

Según el catálogo, Meléndez también posee 11 volúmenes del abad Pluche: los 9 de Le spectacle de la nature (París, 1752) y los dos de la Histoire du ciel, sin más datos. Si el primero es un verdadero best seller de la historia natural dieciochesca, ambos suponen una contundente apología del cristianismo, bien desde la historia natural, bien desde la historia de las polémicas teológicas. En el extenso título del Spectacle de la nature, ou Entretiens sur les particularités de l'histoire naturelle qui ont paru les plus propres à rendre les jeunes gens curieux et à leur former l'esprit (1732), Pluche no revelaba su verdadera finalidad, o cómo quería formar a los jóvenes curiosos, pero ya nos recordaba Richard Herr que, "by spreading knowledge of the latest scientific advances in easily digested form, Pluche sought to inspire reverence for God and his marvellous works ${ }^{44}$. Por otro lado, la Histoire du ciel (1739) habría proporcionado a Meléndez un verdadero arsenal de conceptos, fuentes y metáforas sobre el cosmos pues, más allá de su voluntad de combatir la herejía, como indica el esclarecedor subtítulo de la primera edición, se trata de una historia "considéré selon les idées des poètes,

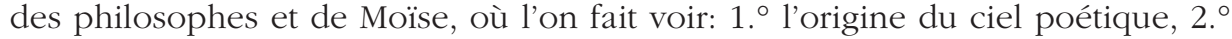
la méprise des philosophes sur la fabrique du ciel et de la terre, $3 .^{\circ}$ la conformité de l'expérience avec la seule physique de Moïse».

Y, entre los 18 volúmenes de las Oeuvres d'bistoire naturelle et de philosophie de Charles Bonnet (Neufchâtel, 1779) ${ }^{45}$, disponía de la Contemplation de la Nature

44. HERR, Richard. The Eighteenth-Century Revolution in Spain. Princeton (NJ): Princeton University Press, 1969, p. 42. Veáse también: Gevrey, Françoise; Boch, Julie y HaqueTte, Jean-Louis (eds.). Écrire la nature au XVIIIe siècle: autour de l'abbé Pluche. Paris: Presses Paris Sorbonne, 2006.

45. ANDERSON, Lorin. "Charles Bonnet's Taxonomy and Chain of Being". Journal of the History of Ideas, 1976, 37.1, pp. 45-58; Duprey, Laura. "L'idée de chaîne des êtres, de Leibniz à Charles Bonnet". Dix-huitième siècle, 2011, 43, pp. 617-637. 
(1764), y en ella de la imagen de la cadena del ser, desarrollada como una gradación ascendente desde el átomo hasta los ángeles ${ }^{46}$.

A todo este corpus que se rastrea en el epistolario y catálogo de 1782, hay que sumar, necesariamente, a otros tres poetas a los que no se ha prestado atención pese a que el propio Meléndez los cita explícitamente como autores de referencia para sus poemas filosóficos y la renovación poética europea nada menos que en el prólogo a la edición de 1797: Haller, Utz [sic] y Cramer (OV, I: p. 67).

La alusión al poeta científico por excelencia está plenamente justificada por el renombre internacional de Los Alpes (1729), en que Albrecht von Haller entrevera observaciones propias de la historia natural con lo sublime alpino interpretado como signo de la grandeza de Dios, pero suyos son también poemas como Über den Ursprung des Übels (1734, Sobre el origen del demonio) o Unvollkommenes Gedicht über die Ewigkeit (1736, Poema inacabado sobre la Eternidad). Meléndez se hizo con una edición de sus obras poéticas en francés en $1785^{47}$.

En cuanto a Johann Andreas Cramer, traductor y continuador de la Historia de Bossuet, pero célebre por su traducción de los Salmos (1755) en la estela de Klopstock, su mención supone la reivindicación de la sublimidad de la elocuencia sagrada del Antiguo Testamento que ya planteaba Longino ${ }^{48}$.

Más difícil es establecer el nivel de conocimiento que Meléndez pudo tener de la poesía de Johann Peter Uz, cuya Versuch über die Kunst stets fröhlich zu seyn (1760) había sido publicada en 1787 como el Arte de ser feliz, en traducción de Bernardo María de Calzada y junto a otros poemas de Christian Fürchtegott Gellert $^{49}$. Dado el contexto, cabe pensar que no se referirá tanto a sus odas anacreónticas (1746), como a su poesía filosófica, con obras tan emblemáticas -y significativas en lo que ahora hace al caso- como la Teodicea (1755), Gott im Ungewitter (1768) o Gott der Weltschöpfer (1768). En Dios en la tormenta, se impone la grandeza de un dios amical que restituye el orden - "Der Herr ist groß! Was trotzen wir?», «Er herrscht mit schonender Geduld, / Der große Menschenfreund!»-;

46. Obviamente, no todas las obras del catálogo sobre historia natural son de este corte; frente a todas ellas, Meléndez había adquirido también la reciente edición de Les époques de la nature (1778; París, 1780), suplemento de Buffon a la exitosa Histoire naturelle, que rompía con las teorías cosmogónicas y proponía una versión geológica de la creación, que abarcaba desde el momento en que el planeta tomaba forma a la aparición de los primeros seres vivos, la retirada del océano que cubría la tierra, la división de los continentes y la aparición del hombre.

47. Demerson, Georges. Don Juan Meléndez Valdés y su tiempo, t. I, p. 153.

48. SHEEHAN, Jonathan. "After prophecy: the poetic Bible and the recuperation of the Old Testament». En The Enlightenment Bible. Princeton (New Jersey): Princeton University Press, 2005, pp. $152-160$.

49. UTz, Johann Peter. Arte de ser feliz, dividido en cuatro epistolas morales en prosa, escrito en alemán: su autor: Utz. Con otras dos epistolas, la una intitulada "La Riqueza y la Gloria", y la otra "El Amigo de los hombres", ambas escritas en el mismo idioma: su autor Gellert. Madrid: Imprenta de Pantaleón Aznar, 1787. 
y Dios, el creador comienza invocando el vuelo sideral a través de las esferas hacia la divinidad: "Zu Gott, zu Gott flieg auf, hoch über alle Sphären!» ${ }^{50}$.

A la vista de lo expuesto, tenemos constancia de que, en ese período que va desde 1776 hasta 1782, Meléndez, más allá de fuentes poéticas como Pope, Young, Milton y Thomson, maneja el propio Ensayo de Locke y la Teodicea o la doctrina pitagórica; se hace con la literatura apologética del cristianismo que vincula el estudio de naturaleza y el cosmos a la divinidad -Pascal, Polignac, Stay, Racine-, constituida en buena parte por poemas filosóficos que contestan el ateísmo lucreciano; y dispone de un nutrido corpus ensayístico de historia natural, que, impregnado por una visión teleológica y teísta de la naturaleza -Clarke, Niewentyt, Pluche, Bonnet-, hace un uso apologético de la ciencia al servicio de la religión. Recurriendo a los argumentos newtonianos para contrarrestar el materialismo y el ateísmo, en un peculiar maridaje entre la nueva ciencia y la teología, la propuesta en el fondo quedaba amparada por el propio aserto de Newton en el General Scholium de que "this most beautiful system of the sun, planets, and comets, could only proceed from the counsel and dominion of an intelligent and powerful Being. [...] This Being governs all things, not as the soul of the world, but as Lord over all. [...] All that diversity of natural things which we find, suited to different times and places, could arise from nothing but the ideas and will of a Being necessarily existing, ${ }^{51}$. Si en la ciencia newtoniana el Supremo Artífice actualiza el antiguo argumento cosmológico, en este corpus que de él proviene todas las maravillas descritas, desde la metamorfosis de un insecto a las leyes astronómicas, son narradas ad maiorem Dei gloriam, como sucederá, de hecho, en los poemas filosóficos de Meléndez Valdés ${ }^{52}$.

Obviamente, esto no implica que estas lecturas constituyan una fuente de los poemas filosóficos de Meléndez en el sentido positivista del término que cuestionaba Pedro Salinas, como una presencia material de un texto en otro. Pero, dada la relevancia numérica entre 1776 y 1782 de estas obras en que lo científico y lo natural está orientado hacia lo teológico, sí creo que funcionaron como esos hipotextos más vagos, dinámicos y subyacentes que quería Genette; y que son también marco y contexto de los poemas filosóficos sobre lo sublime cósmico de Meléndez, unas rutas intelectuales en que el poeta, que no solo lee a poetas, aprehendería una estética y una retórica argumentativa para formular su propia

50. UTz, Johann Peter. Poetische Werke. Leipzig: Dyck, 1768.

51. JACOB, Margaret C. The Newtonians and the English Revolution 1689-1720. Ithaca: Cornell University Press, 1976; BROOKE, John H. Science and Religion: Some Historical Perspectives. Cambridge: Cambridge University Press, 1991.

52. El papel fundamental que los avances científicos jugaron en la nueva poesía filosófica es puesto de relevancia con tino en: JONES, William Powell. The Rhetoric of Science: A Study of Scientific Ideas and Imagery in Eighteenth-century English Poetry. Berkeley: University of California Press/London: Routledge and Kegan Paul, 1966. 
teodicea, en sintonía con la poesía ${ }^{53}$, pero también con el pensamiento contemporáneo europeo.

\title{
3. ACERCAMIENTOS PRIMEROS (-1785): «MI PACÍFICA MUSA NO AMBICIOSA SE ATREVE A TANTO»
}

En la epístola en que Meléndez dedica a Jovellanos el primer tomo de sus poesías (ed. 1785; OV, II: pp. 763-767), que teniendo mucho de introito retórico no deja de contener ciertas trazas de poética, decía Batilo que otros escribirán poesía épica, satírica, «o bien al cielo su tono alzando explicarán las leyes / con que en torno del sol la tierra gira / quién la luz lleva hasta Saturno, o cómo / del desorden tal vez el orden nace / y este gran todo invariable existe», pero "mi pacífica musa no ambiciosa / se atreve a tanto". También leemos en la oda anacreóntica XXVII, De las ciencias, publicada en ese mismo volumen (-1784; ed. 1785; OV, I: p. 104):

\author{
Aténgome a mi Baco, \\ que es risueño y afable; \\ pues los sabios, Dorila, \\ ser felices no saben. \\ ¿Qué me importa que fijo \\ cual un bello diamante \\ esté el sol en el cielo, \\ como él nazca a alumbrarme? \\ La luna está poblada... \\ mas, que tenga millares \\ de vivientes, pues que ellos \\ ningún daño me hacen.
}

53. En cuanto a estos poemas y más allá de citas puntuales, convendría recordar que el carácter general de lo sublime cósmico del Essay on Man de Pope podría condensarse en el verso "[the good] looks thro' Nature up to Nature's God" [Pope, Alexander. Essay on Man, ep. IV, "Of the Nature and state of Man, with respect to Happiness", VII, v. 332. En The Poems of Alexander Pope. Edición de John, Butt. London: Butler \& Tanner (University Paperbacks), 1965, p. 546]. Y también que la argumentación general de los Night Thoughts intenta hacer frente al ateísmo del joven Lorenzo, pues apela a su razón y sus sentidos como un modo de acceso a la verdad última, para probar que la naturaleza misma revela la existencia de un Creador. Incluso es posible que bajo Young lata de nuevo Addison, como sostiene Anne Janowitz, que señala que Young "reformulates the Addisonian sublime of infinite worlds» y reconoce ecos de Addison en versos tan emblemáticos de los Night Thoughts como "what swarms / of worlds that laugh at earth! Immensely great! / Immensely distant from each other's spheres! / What, then, the wondrous space through which they roll? / At once it quite engulfs all human thought; / 'Tis comprehension's absolute defeat" (JanowiTz, Anne. "The Sublime Plurality of Worlds: Lucretius in the Eighteenth Century». Tate Papers, Spring, 2010, 13: http://www.tate.org.uk/research/publications/ tate-papers/13/the-sublime-plurality-of-worlds-lucretius-in-the-eighteenth-century). 
Pese a estos versos, que no dejan de recordar a los de un metapoema de Cadalso $^{54}$, al poeta sí que le importaba y la musa ya se había atrevido. En 1787 Sempere y Guarinos proporciona un listado de poemas que Meléndez tenía previsto haber impreso en ese segundo tomo que no vio la luz y que iba a ofrecer "poesías de carácter más grave»: El cántico de muerte, Himno a la Naturaleza, Los cielos, Las pasiones y la virtud, La dignidad del hombre, Locura y vanidad de sus deseos, Lo incomprensible de Dios, La prosperidad del malo, La noche y la soledad, Canción fúnebre a su amigo D. José Cadalso, Reflexiones en un templo y La caída de Luzbe ${ }^{5}$. Aunque algunos títulos no coinciden exactamente con los editados en 1797, alcanzan a evidenciar que muchos de ellos ya transitan lo sublime cósmico ${ }^{56}$.

Es el caso de la que precisamente se dice, en nota de la edición de 1820, la "primera composición filosófica del autor", la conocida oda VIII La noche y la soledad, que vio la luz en el Correo de Madrid el 23 de junio de 1790 (1779-1780; ed. 1797; OV, II: pp. 874-875)57. En cuanto a lo sublime en esta oda, James Mandrell destaca el "pure terror in the service of self-preservation" subrayando la emoción de terror ante la muerte en las alusiones al "sepulcro pavoroso", los "fétidos gusanos", el "polvo» y los "lúgubres gemidos», concluyendo que:

54. Refiere el autor los motivos que tuvo para aplicarse a la poesía y la calidad de los asuntos que tratará en sus versos: "Y di, lector: ¿acaso nos importa / (pues la vida es tan frágil y tan corta) / que Febo dé su vuelta concertada, / siendo la tierra la que está parada, / o que, parado el sol, la tierra suelta, / alrededor de Febo dé la vuelta?» (CADALSO, José de. Ocios de mi juventud. Ed. Miguel Ángel Lama. Madrid: Cátedra, 2013, p. 149).

55. SEMPERE y GuARINos, Juan. Ensayo de una biblioteca de los mejores escritores del reinado de Carlos III. Madrid: Imprenta Real, 1787, t. IV, p. 60. La referencia ya la proporciona COLFORD (Juan Meléndez Valdés. A Study in the Transition from Neoclassicism to Romanticism in Spanish Poetry, p. 20), y es manejada por Demerson (Don Juan Meléndez Valdés y su tiempo, t. I, pp. 230-233; t. II, pp. 379-380) y John H. R. POlt (Batilo: Estudios Sobre la evolución estilística de Meléndez Valdés. Oviedo: Centro de Estudios del Siglo XVIII, 1987, pp. 313-314).

56. Algunas consideraciones sobre lo sublime y la cadena de los seres en la poesía de Meléndez Valdés ya se plantearon en "La cadena de los seres: noción filosófica, hipótesis científica y tópico literario" y en "La cadena de los seres, la teoría de lo sublime y la literatura inglesa". En Nuevos mundos poéticos. La poesía filosófica de la Ilustración. Oviedo: IFESXVIII, 2000, pp. 253-280.

57. POLT señala que la oda XXIV A la mañana, en mi desamparo y orfandad (1777; ed. 1797; OV, II: pp. 666-668), escrita poco después de la muerte de su hermano Esteban, es una de las obras en que más tempranamente se percibe un cambio de orientación poética que el hispanista vincula al magisterio de Jovellanos. En ella no se formula como tal lo sublime cósmico, si bien es cierto que aparecen ya algunos mimbres que forman parte de esta estética, como la querencia por la noche -amiga noche", "Quiérote empero más, oh noche umbría, / que la enojosa luz del triste día»- y por la soledad - "que en la callada noche al menos llora / sola su inmenso mal el alma mía" (Batilo: Estudios Sobre la evolución estilística de Meléndez Valdés, pp. 296-316). Demerson la relaciona con los Night Thoughts en la versión francesa de Le Tourneur (Don Juan Meléndez Valdés y su tiempo, t. II, pp. 191 y ss.); también RaILlaRD: "The final verses of his ode $A$ la mañana could have come straight from Noches lúgubres, with its open longing for the darkness of night: "Quiérote empero más, oh noche umbría, que la enojosa luz del triste día” ("Deism, the Sublime and the Formulation of Early Romanticism in Juan Meléndez Valdés and José de Cadalso", p. 139). 
Meléndez Valdés' description evidences several aspects of Burke's version of the sublime, including pure terror in the service of self-preservation. Although the presentation of the "sepulcro pavoroso" is far removed from Burke's exhaustive discussion of the varying sources of the sublime, terror is still the dominant emotion behind this vision of death, including as it does "fétidos gusanos" and the anguished laments regarding "polvo".

But Meléndez Valdés rejects solitude, symbol of the sublime and of the divine in its mortal aspect, in order to return, with Jovellanos, to the reading of the Night Thoughts. By rejecting transcendence, the poet reveals himself to be incapable of transcending his own situation and of confronting death. The insufficiency characteristic of the sublime -and of the language of the mystics to which the poet alludes "los solitarios»- is an insufficiency not of language, but, rather, of the poet himself. In falling into the sublime style of the eighteenth century, Meléndez Valdés flees the sublime, demonstrating how removed he is from the Romantic view of the world ${ }^{58}$.

Quizá la presencia de este sublime, concentrado en los vv. 285-312, adquiera ciertos matices analizado en contexto. En los casi 300 versos anteriores, Meléndez no solo no rechaza la soledad, sino que desea la noche y la soledad, y no como lugar terrible o temible, sino como reparador ámbito de sosiego: "libra del mar horrísono", trae al corazón herido «benigna la paz y la alegría», levanta el "espíritu abatido", es "favor celestial" que "a un triste conforta", que llena el alma "de otra sublime luz" y "a la verdad inclinas transparente / del cielo refulgente / haciendo que nos abra el hondo abismo / do esconde sus tesoros celestiales".

Frente al mundanal ruido, la soledad y la noche propician la lucidez que emana de la contemplación del universo y revela la trascendencia: «la mente sin los lazos que detienen / su generoso ardor, en raudo vuelo / las vagas nubes pasa, / llegando a do su trono alzado tienen / al inmenso Hacedor los altos cielos, / y a su divina norma se acompasa». La noche es el espacio en que el vuelo de la mente conduce al Hacedor, en que es posible el «silencio augusto, donde Dios habla». Esta reconfortante imagen de un alma acompasada al latir del universo y de una mente que alcanza a comprender el sentido último del cosmos y a reconocer a su Hacedor responde plenamente a lo sublime cósmico, que ya despliega aquí toda su imaginería.

Primero, Meléndez plantea que ante la condición inmortal del hombre es nada el cosmos, y menos las pequeñeces de la vida mundana - ¿Puede a un alma inmortal, con quien son nada / esos soles y globos cristalinos, / tener el bajo suelo a sí apegada, /o en juguetes mezquinos / ocuparte, olvidando el alto grado/ a que el gran Ser al hombre ha sublimado?»-; luego contempla y describe: "Ves las esferas de eternal ventura / reales mansiones del Señor, labradas / por su poder divino, / del sin fin de luceros la hermosura, / todos girando en

58. MANDRELL, James. "The Literary Sublime in Spain», pp. 294-313. 
órbitas variadas, alzándose en el éter cristalino»; y ante tal visión desea: «Cuándo el día será luciente y puro / que en suave soledad contigo unido / [...] tan sublimes verdades contemplemos?»; para luego insistir interrogando "¿Quién puede ver el cielo tachonado / de lumbre tanto y la beldad gloriosa / de la noche serena / [...] que alegre el seno palpitar no sienta / y en suavísimos éxtasis no quede?». Finalmente, el alma aspira de nuevo a una soledad "do atónita al gran Ser doquier admira», en cuyo recinto "siento el ánimo libre y descargado / del peso que me abruman; el yo poético recuerda la trascendencia que los eremitas reconocían en el cosmos; y concluye «iOh, noche! ;Oh, soledad! en vuestro seno / solo hallo el bien y en libertad me miro / [...] y desprendido / de los lazos del cuerpo me levanto / al supremo Hacedor».

Estos casi trescientos versos que conforman el grueso de la oda VIII están organizados como un viaje cósmico - la mente sin los lazos que detienen / su generoso ardor, en raudo vuelo / las vagas nubes pasa»-. Como estudia Marjorie Hope Nicolson en su obra sobre la estética del infinito, este cosmic voyage o excursion es característico de los poemas descriptivos europeos del siglo XVIII, cuyos elementos son muy estables:

The "excursion" was a peculiarly fitting vehicle for a generation of poets even more conscious of science than their predecessors, a philosophical and scientific device that permitted them to wander through space and around the earth and to ponder the nature and causes of things. [...] The "excursion" poets of the eighteenth century rose upon "wings sublime", soared into the Newtonian heavens, then descended to earth where they flew to different lands, plumbed the depths of ocean, and dived "beneath the darksome caverns" into the secret places, constantly reiterating their "delight", "Wonder", "awe», and "astonishment" at the variety and profusion of a Nature made in the image of an exuberant Deity. As they flew or swooped or dived, they philosophized, seeking natural rather than supernatural explanations ${ }^{59}$.

Es después de este viaje cósmico de 286 versos cuando se interroga: «¿Cómo pues insensato el hombre te huye / divina soledad? ¿Cómo lamenta / su venturosa suerte / si en tu seno se ve y al cielo arguye? / ¿Por qué en míseras sombras se contenta?»; y es entonces cuando aparece en tres versos la idea de la muerte presentida y ese sublime lúgubre que se ha identificado como romántico, pero cuyo sentido final creo que matiza plenamente el contexto.

59. NiCOlson, Marjorie Hope. Mountain Gloom and Mountain Glory: The Development of the Aesthetics of the Infinite, pp. 329-336. La autora remite a poemas de John Hughes, Richard Bentley, Edward Young, Richard Savage, David Mallet y James Thomson. También aborda la relación entre lo sublime, lo infinito y estos viajes cósmicos Ángeles García Calderón, analizando los poemas de Lady Mary Chudleigh, John Reynolds, Richard Blackmore, John Hughes y Henry Needler (GARCía CALDERÓN, Ángeles. "La unión entre ciencia y poesía en el primer cuarto del XVIII en Inglaterra». Alfinge, 2010, 22, pp. 119-141). 
Si es cierto que el hombre ha de verse en «sepulcro pavoroso / en ciega noche y soledad, comida / de fétidos gusanos", no lo es menos que a verso seguido se alude a una reconfortante resurrección, "hasta que agrade al Todopoderoso / con su imperiosa voz darle otra vida, / alzándole del polvo con sus manos?»; del mismo modo que el terror de "ver que en ansias tan graves / solo te hace otro polvo compañía» es solo para aquel que no sabe "vivir en soledad", que es lo que conduce a ese final en que se invoca al amigo, para compartir la lectura de los Night Thoughts: "Tú, dulce amigo, que el valor conoces / de la meditación, y el alma cuánto / con el retiro gana, / ven, y esquivadas turbulentas voces, / al cuidado civil te roba en tanto / que el sonrosado manto de oro y grana / desplega la mañana; / y con Young silenciosos nos entremos / en blanda paz por estas soledades / do en sus Noches sublimes meditemos / mil divinas verdades; / y a su voz lamentable enternecidos, / repitamos sus lúgubres gemidos».

La alusión a la muerte potencia por contraste lo sublime de la omnipotencia divina, que finalmente se impone; del mismo modo que la ansiedad que produce la visión de ese polvo en que se convertirá es desplazada por la meditación, esa reflexión sobre la trascendencia que en ese locus silencioso y solitario atempera la desesperación y conduce a la "blanda paz".

Lo sublime reaparece dos años después en la oda V, La gloria de las artes (1781; ed. 1785; OV, II: pp. 860-869), un poema que Meléndez debió de trabajar a conciencia, pues iba a ser leído en sesión plenaria de la Academia de San Fernando con motivo de la distribución de los premios concedidos a los discípulos, lo que de algún modo suponía su puesta de largo como poeta en una corte a que acababa de llegar ese mismo año y tras haber merecido el premio de la Academia Española por la égloga Batilo.

Aquí era el "alma sublime» de Rafael la que «el denso velo / corrió con noble anhelo / de la naturaleza, y vio pasmado / el hombre ante sus ojos reverente / el universo estar, y hermoseado / de su mano salir y augusta mente!». Pero en este poema, como conviene al caso, lo sublime no surge de la admiración ante la creación sino ante la capacidad creativa del hombre - Admira, oh hombre, tu grandeza; admira / tu espíritu creador, y a la estrellada / mansión vuela seguro / donde tu aliento celestial suspira»- y Meléndez pasa a concentrarse en lo sublime artístico. No deja de resultar significativo, en todo caso, que a continuación Meléndez se ocupe del Laocoonte contraponiéndolo al Apolo de Bellvedere, en clara oposición entre lo sublime y lo bello, y describa al sacerdote troyano, emblema de lo sublime artístico, subjetivizando la descripción: «en su crudo / dolor escuchar creo / los gemidos del pecho congojado, / y al aspirar alzado", intentando liberarse de los "cuerpos sanguinosos" de los "hórridos dragones": «Mira cómo en su angustia el sufrimiento / los músculos abulta y cuál violenta / los nervios extendidos! / ¡cuál sume el vientre el comprimido aliento / y la ancha espalda aumenta!». 
En $1782^{60}$ Meléndez vuelve a lo sublime cósmico en la oda X, dedicada a Jovellanos y posteriormente a Felipe Palafox (ed. 1797; OV, II: pp. 885-888). La crítica ha constatado con detalle la influencia de Pope y Young en Vanidad de las quejas del hombre contra su Hacedor ${ }^{61}$, cuyo eje es la cadena del ser y el orden del universo. Como explica Rinaldo Froldi: "Dio è un ordinatore supremo che ha disposto con assoluta saggezza, legandole fra loro, tutte le cose; quindi è vano e insieme colpevole pretendere di varcare il proprio stato, tentare d'uscire dalla condizione in cui ci si trova ${ }^{62}$.

Ya en el arranque de la oda, el "Hacedor divino" aparece como autor "de esta fábrica hermosa" y responsable de "este todo inmenso y peregrino", pero el hombre osado «romper quiere, / vasallo rebelado / aquel vínculo estrecho / que cada parte a su lugar refiere / y ata y sostiene cuanto está creado", pese a que "Todo está colocado / cual debe en su gran obra; y nada puede / del círculo salir que le ha cabido". El poema gira en torno al motivo del hombre orgulloso que quiere ocupar el lugar de los ángeles y se ubica en el centro del universo, desbaratando el orden divino. Para advertir cuál es su verdadero lugar en el mundo el hombre debe estudiar el universo, y «la modesta razón» le mostrará lo sublime de la naturaleza -«ve la inmensa cadena / que ata el abismo al cielo»- y le permitirá comprender sus leyes, "cuando el hombre alcanzar pueda / qué es la hoguera del sol, de dónde viene / la lluvia y el rocío, / qué fuerza impele a la celeste rueda, / dónde suspenso el universo tiene / de Dios el infinito poderío». A continuación, la adversativa "Mas no tanto» marca los límites de dicho conocimiento, porque los descubrimientos no son más que

60. Razonan Polt y Demerson (OV, II: p. 884) que, dado que en un manuscrito el poema se dedica a Jovellanos especificando que es miembro del Consejo, ha de ser posterior a agosto de 1780 $\mathrm{y}$, por el tratamiento, anterior a abril de 1782 y con seguridad a su lectura ante la Bascongada en Junta de entre 27 de septiembre y 2 de octubre de 1783. La fecho en 1782 porque creo que está vinculada a la epístola $\mathrm{V}$ de Jovellanos de ese mismo año (Nuevos mundos poéticos. La poesía filosófica de la Ilustración, pp. 272-273).

61. Ya COLFORD apuntó que "all this sounds much like Pope's Essay on Man and his dictum "Whatever is, is right" (Juan Meléndez Valdés. A Study in the Transition from Neoclassicism to Romanticism in Spanish Poetry, p. 191), pero es Forcione quien analiza en profundidad las correspondencias entre ambos poemas: «So close are the correspondences between the two poems in ideas, construction, and phrases as to exclude all doubt that Meléndez took Pope's Essay as his model» («eléndez Valdés and the Essay on Man", p. 293). Cabe reseñar que Fess vinculaba el poema a los Pensées de Pascal ("Meléndez Valdés' Vanidad de las quejas del hombre contra su bacedor and the Pensées of Pascal", pp. 282-284) y que GLENDINNING percibe también la influencia de versos de Young y ecos de la traducción de Le Tourneur: en los versos «La luna plateada para él sólo / no recibe la luz que al suelo envía?» señala ecos de los de Young: "Hangs out the sun his lustre but for me, / the single man?» (I, vv. 131-140), aunque subraya que hay un pasaje similar en el Essay on man de Pope; y apunta en "la inmensa cadena / que ata el abismo al cielo. / Del infinito en medio y de la nada, / ¿qué es el hombre ignorante?» ecos de la traducción Les Nuits de Le Tourneur «il occupe le milieu dans la chaîne immense des êtres qui descend depuis Dieu jusqu'au néant» ("Influencia de la literatura inglesa en España en el siglo XVIII", pp. 81-89).

62. Froldi, Rinaldo. Un poeta illuminista: Meléndez Valdés. Milán: Cisalpino, 1967, p. 96. 
vislumbres que el siervo hace de los secretos del señor; solo la visión en perspectiva del viaje cósmico permite percibir el orden e inmensidad del cosmos y la variedad de sus criaturas, que implican la admiración y el reconocimiento del verdadero lugar que el hombre ocupa en la creación.

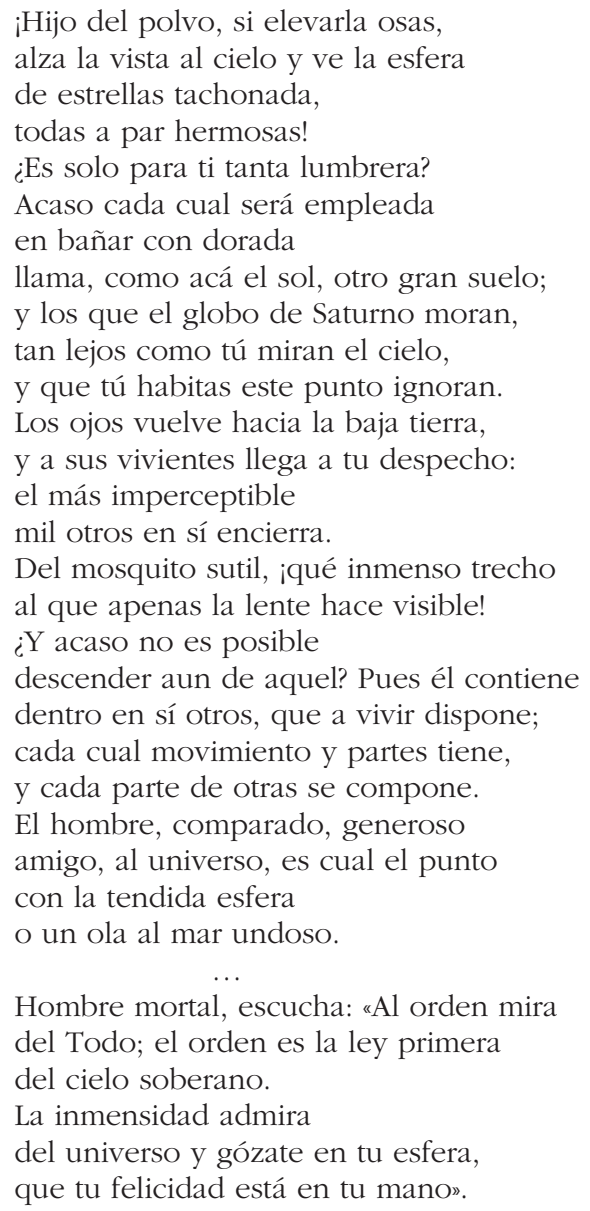

La idea de inmensidad del cosmos y abundancia de estrellas conduce con naturalidad hacia la posibilidad de la existencia de vida en otros planetas, en este caso Saturno, en los confines del sistema conocido -Herschel solo daría noticia de Urano precisamente en 1781-. La habitabilidad de los mundos ya derivaba directamente de su pluralidad en los Entretiens sur la pluralité des mondes (1686), que Meléndez poseía y en que Fontenelle divulgaba con éxito la argumentación de una posible vida extraterrestre. Defendida en el siglo XVII ya en los viajes a la 
Luna de Kepler, Wilkins, Godwin o Cyrano de Bergerac, había sido difundida en el ámbito hispánico por Feijoo en los ensayos "Corruptibilidad de los cielos» o "¿Si hay otros Mundos? ${ }^{63}$.

Paralelamente, y según la transición ya marcada por Addison, si el telescopio había permitido percibir esta multitud de estrellas y planetas, el microscopio revelaba la existencia de los más minúsculos seres: de ahí la contraposición entre el mosquito y esos microorganismos aun menores que Leeuwenhoek llamaba "animálculos» y que ni siquiera serían el último peldaño de la escala de los seres. El hallazgo de estos seres diminutos implica la continuación de la naturaleza y de la cadena que la une y refuerza la idea de infinitud más allá de lo que se percibe a simple vista, lo que admira, sorprende y estimula la imaginación y, en última instancia, revela la existencia de Dios.

En el título del manuscrito en que esta canción filosófica aparece dedicada a Jovellanos se resalta la orientación final hacia la alabanza divina de este tópico: «El hombre tiene toda la perfección debida al lugar que ocupa en la escala de los seres creados. Locura y vanidad de sus quejas contra el Hacedor».

Creo que el poema se halla vinculado a la epístola V de Jovellanos (1782), dedicada a Batilo, por las dedicatorias mutuas, su estricta contemporaneidad y el asunto de los poemas. En la epístola del asturiano, la visión de la vega del Bernesga motiva el desengaño de corte y alabanza de aldea, y Jovino insta a Batilo a abandonar el "bullicio de las altas ciudades" y las "sombras vanas» para dedicarse a la contemplación del espectáculo del universo. En los términos descritos, la propuesta resulta ser un programático plan de reflexión sobre lo sublime cósmico, pues presenta las ideas del universo como un código y de que la contemplación del orden en los cielos y el infinito de estrellas lo conducirán al reconocimiento de la existencia divina.

Incluso aunque no estuvieran directamente vinculados, es de interés percibir la intertextualidad, pues a principios de los ochenta los dos autores que lideran la renovación poética abordan lo sublime cósmico en obras que se dedican mutuamente.

Corre, vuela,

y si la sed de más saber te inflama,

no creas que entre gritos y contiendas

la saciarás. ¡Cuitado! No lo esperes,

que no escondió en las aulas rumorosas

sus mineros riquísimos Sofía.

Es más noble su esfera: el universo

es un código; estúdiale, sé sabio.

Entra primero en ti, contempla, indaga

la esencia de tu ser y alto destino.

63. TCU, VIII, p. 7 (1739); CEC, II, p. 26 (1745) 
Conócete a ti mismo, y de otros entes

sube al origen. Busca y examina el orden general, admira el todo, y al Señor en sus obras reverencia. Estos cielos, cual bóveda tendidos sobre el humilde globo, esa perenne fuente de luz, que alumbra y vivifica toda la creación, el numeroso ejército de estrellas y luceros, a un leve acento de su vOz sembrados, cual sutil polvo en la región etérea;

esta, en fin, varia y majestuosa escena, que de tu Dios, la gloria solemniza, a sí te llama y mi amistad alienta ${ }^{64}$.

También es de interés relacionar Vanidad de las quejas del bombre contra su Hacedor con la oda XXV a la muerte de Cadalso, considerando que Meléndez señala que Dalmiro "fue el primero que sublimó nuestros tiernos ojos hasta los cielos y nos hizo ver en ellos las inmensas grandezas de la creación" ${ }^{65}$. Aunque estrictamente contemporáneas (1782), ambas odas contrastan totalmente. Dominada por el locus eremus en que Batilo lamenta la muerte de Dalmiro, el inicial «Silencio augusto, bosques pavorosos, profundos valles, soledad sombría / altas desnudas rocas, que solo precipicios horrorosos / mostráis a mi azorada fantasía”, conduce al «laberinto más umbrío / do mi melancolía / del silencio y el duelo acompañada / se pierda libre», y solo en este "valle lóbrego y medroso, / de riscos y altos árboles cercado, / que en eco lastimoso / el nombre infausto de mi amigo suena, / mi pecho adula y su dolor serena». Dalmiro reposa en la mansión de la muerte: "allí cerrado / con llave de diamante la espantosa / eternidad le guarda aprisionado / en noche tenebrosa»; y ante esta "terrible eternidad", "Vasto océano donde todo se pierde», la Naturaleza "al abismo insondable de la nada / desciende despeñada» (ed. 1820; OV, II: pp. 936-940).

En esta oda ningún elemento matiza ni reconduce ese sublime lúgubre, lo que puede deberse a que ignoramos hacia dónde nos habría conducido el poema, cuyo final desconocemos si, como se señala en la edición de 1820, quedó inconcluso. Aunque Polt y Demerson dudan de tal aserto, creo que refrenda que se trata de una obra inacabada el hecho de que en vida de Meléndez se reprodujera reiteradamente solo su inicio: sus ochenta primeros versos fueron conocidos gracias a que los publicó Sempere, quizá con anuencia del autor, en su Ensayo en 1787,

64. GMJ, OC, I: pp. 193-197.

65. MelÉndez VAldés, Juan. Obras completas. Ed. Emilio Palacios Fernández, t. III, pp. 394-395. 
y fueron reproducidos en el Diario de Madrid en 1795 y luego en las Variedades de Quintana en 1803.

Sí se reconduce lo sublime en la también inconclusa y cercana cronológica y temáticamente oda XXXVII, Mi cántico de muerte (1786; OV, II: pp. 982-983), que puede ser El cántico de muerte que reseña Sempere. Aunque básicamente es un plan de poema, este muestra que a ese «eternal reposo / [que] al polvo deleznable / ofrece ya el sepulcro pavoroso", seguía la reconfortante confianza en la divinidad: "A la mía, el Señor que te crio te guarda; él te protege en este día; mira sus ángeles santos, etc. Oye, Señor, mi ruego, porque cerca de ti está la misericordia. Yo cantaré las alabanzas del Señor cerca de su trono y acompañaré los himnos de alabanza entre sus ángeles».

En 1785 Meléndez presenta al concurso de la Real Academia Española La caida de Luzbel (ed. 1797; OV, II: pp. 1060-1075). Poco hay que interpretar sobre la elección del tema y su tratamiento, pues el primero venía marcado por la institución ${ }^{66}$, y la crítica ha analizado certeramente la influencia del Paradise Lost de John Milton ${ }^{67}$. En todo caso, la revisión en 1777-1778 de la traducción de Jovellanos del primer canto dejó temprana huella en el joven Meléndez ${ }^{68}$ y hubo de hacerle reparar en la estética del infinito que signa el poema que puso de moda el culto de la sublimidad literaria ${ }^{69}$. Y en esta clave sublime se leía el poema entonces, como demuestra la serie Criticism on Milton's "Paradise Lost" publicada por Addison en The Spectator (31/12/1711-3/5/1712): señala que el asunto de la caída de Luzbel es "the most sublime that could enter into the thoughts of a poet» (n. ${ }^{\circ}$

66. Para los concursos de la RAE ha de consultarse RODRíGUEZ SÁNCHEZ DE LEÓN, María José. «Los premios de la Academia española en el siglo XVIII y la estética de la época». Boletín de la Real Academia Española, septiembre-diciembre 1987, tomo LXVII, cuaderno CCXLII, pp. 395-425.

67. Al margen de las apreciaciones de Peers, Colford y, especialmente, DemERSON (t. II, pp. 189200 y 243), la influencia de Milton puede contextualizarse en PEGENAUTE, Luis. «La recepción de Milton en la España ilustrada: visiones de El paraíso perdido". En LAFARGA, F. (ed.). La traducción en España, 1750-1830: lengua, literatura, cultura. Lleida: Universitat de Lleida, 1999, pp. 321-334.

68. «Hemos recibido la traducción del célebre Paraíso perdido y hoy no hemos leído más que la mitad antes de las nueve. Nos ha llenado infinito. El espíritu seco del original lo explica grandemente; la frase es llena y grandílocua y el verso majestuoso y claro. ¿Quién creyera que el dulce mayoral Jovino, allá a las orillas del Betis, haría resonar otra vez la lira del cantor de la primera desobediencia y volvería a encender los volcanes del Homero inglés? Mi voto es el mismo que el de los señores de esa ciudad, y lo mismo juzga Delio; pero, no obstante, cuanto notemos lo iremos apuntando y acá, digámoslo así, le daremos otra lira en lo que alcanzare mi pequeñez» (18/10/1777, GMJ, OC, II: p. 99; la traducción de Jovellanos en GMJ, OC, I: pp. 97-126). "Ahí tiene V.S., por último, el Milton enmendado. [...] Lo que resta es que V.S. me mande cuanto antes el segundo canto. [...] No di ciertamente el Milton al irlandés para que lo enmendase, porque ¿qué conocimiento pudiera tener un extranjero de nuestra lengua? Sino que, como notaba alguna variación en la traducción francesa y la de V.S., hacía que me volviera el original a nuestro castellano literalmente, para ir así cotejándole mejor (3/8/1778; OC, II: 99. 134-135).

69. NiCOLSON, Marjorie Hope. Mountain Gloom and Mountain Glory: The Development of the Aesthetics of the Infinite, pp. 273-276. 
333, 22/3/1712); vuelve a lo sublime como uno de los modos de lo bello: «some passages are beautiful by being sublime, others by being soft, others by being natural» (n. ${ }^{\circ} 369,3 / 5 / 1712$ ); y elogia a Milton en estos términos: "The poet runs on with the hint, till he has raised out of it some glorious image or sentiment, proper to inflame the mind of the reader, and to give it that sublime kind of entertainment which is suitable to the nature of an heroic poem» (n. ${ }^{\circ} 303,16 / 2 / 1712$ ).

Aunque el poema de Meléndez incurre desde la primera octava en rimas imperdonables que creo que justifican plenamente que no fuera premiado -Luzbel «quiso triunfante y orgulloso / junto a la silla de Jehová su silla, / negándose a doblarle la rodilla»-, ya en las primeras estrofas se describe la creación en términos de un sublime cósmico signado por el orden y la inmensidad - «En el principio, el brazo Omnipotente / los cielos extendido acaso había / y en su ancho espacio el escuadrón luciente / de soles ya ordenado discurría; / en la nada tal vez confusamente / la inmensa creación se contenía»-; sublime será también luego el escenario de la iracunda Justicia y el Dios airado ante la rebelión: "Ardía en llamas vivas la montaña / y en nubes de humo el trono luminoso / se oscureció; tronó su inmensa saña / tres veces con son hórrido, espantoso"; o el momento en que los arcángeles y sus batallones se aprestan a la lucha: «Las prestas alas súbito desplegan / entre salvas de bélica armonía / y más veloces que los rayos llegan / del solar globo hasta la tierra umbría; / con sesgo vuelo rápidos navegan / del vasto espacio la región vacía, / con quien el ancha tierra fuera nada / toda en una sola línea prolongada».

Son solo algunas calas en un extenso poema en que la inmensidad del universo es el espacio del enfrentamiento más sublime que se podía concebir -a tenor del carácter de protagonistas- y se plasma en potentes escenas de perspectiva cósmica, que acogen tormentas, huracanes y plagas bíblicas dignas de un Armagedón: "Como cuando, / consumados los siglos, en el cielo / la pavorosa trompa resonando, / se hundan los montes al abismo, el suelo / se suba a las estrellas, fluctuando / los astros choquen entre sí, de duelo / se vista el día, caiga despeñada / naturaleza al seno de la nada».

Lo sublime cósmico reaparece también lateralmente en esas fechas en el extenso discurso II El hombre fue criado para la virtud, y solo halla su felicidad en practicarla (-1786; ed. 1797; OV, II: pp. 1036-1044), que arranca "¿Nació, Amintas, el hombre / para correr tras la apariencia vana, cual bestia, del placer?», y a que Forner contesta con el discurso V de sus Discursos filosóficos sobre el hombre en 1787.

En él es «vano alarde» querer "de tanto sol luciente [...] / medir el velocísimo camino / [...] del más vecino / planeta al más lejano / pesar la mole inmensa» o «al lóbrego abismo de la tierra / calarse y cuidadoso / cuanto ser raro y misterioso encierra / su ancho seno explorar", si no se reconoce el alto fin del universo. Y en ello abunda el poeta al exponer que toda la Naturaleza sigue el designio divino: «En raudo vuelo / rodea la tierra el luminar del día / con ley igual por la región vacía. / Miles de soles el inmenso cielo / sin tropezarse cruzan". Por lo que insta a la reflexión - «De no meditar nace / nuestro mísero estado»- y exhorta 
a Forner: "Cultiva, pues, esta razón, si anhelas al verdadero bien». Dicha razón consiste en la indagación "de cuanto el cielo inmensurable encierra / y la ancha faz adorna de la tierra?», y revela el orden de la Naturaleza y la cadena del ser, que demuestran la existencia de Dios: «¿Su luz hasta el gran Ser no te encamina, / de ente tanto la escala peregrina / siguiendo? ¿No le ves en el lumbroso / ardiente sol sentado?».

La naturaleza sublime reaparece ese año en la Epístola V. A Gaspar González de Candamo (1786; ed. 1797; OV, II: p. 780), en que, con motivo de la partida del catedrático de Hebreo a América, lo anima al estudio de la Naturaleza: «iA tu mente curiosa qué de objetos / van a ostentarse ¡cuánta maravilla / a ese tu genio observador aguarda!». Como corresponde a la naturaleza americana, no solo se halla caracterizada por la habitual variedad, sino también por la alteridad: "Otro cielo, otra tierra, otros vivientes, / plantas, árboles, ríos, montes, brutos, / insectos, piedras, minerales: todo / todo nuevo y extraño». En todo caso, puede llegar a comprenderla, siempre que la estudie con una actitud trascendente, que es la que permite percibir el fin último: «admira, estudia / la gran naturaleza y con divina / mente su inmensidad feliz abarca».

Siguiendo las pistas de Sempere y Guarinos de lo que podría haber sido el segundo tomo de 1785 , se podrían considerar redactados en la década del 80 otros dos poemas.

Por un lado, el Himno a la Naturaleza sería la oda XIX Inmensidad de la Naturaleza y bondad inefable de su Autor, que comienza precisamente: «iOh, gran Naturaleza, / cuán magnífica eres! / ¡Cuánto el Señor te enriqueció de seres en profusa largueza!» (ed. 1797; OV, II: pp. 915-920). La cadena de los seres reaparece convertida en eje de una oda cuyo título vuelve a vincular inequívocamente lo sublime de la naturaleza al argumento de la existencia y la bondad divinas; y presenta las referencias habituales a la abundancia y la variedad: se señala la "profusa largueza" de los entes, finalmente incontables - ¿qué espíritu bastante / será a contar los hijos que en perenne / verdor tu seno próvido mantiene?»-, y su diversidad en tamaño e importancia -el musgo y el álamo, el arador y el elefante, el polvo terrestre y el globo inmenso del sol-. La mirada hacia la tierra desemboca en una imagen de alcance cósmico, en que el yo percibe el "glorioso ejército sin cuento" de estrellas, la "inmensa" esfera por la que vagan cometas, los soles que se apiñan "cual la arena del mar" y adornan una naturaleza "sin fin» y "sin número». Incontable e inmensa, la mente reconoce luego en ella una sucesión de grados de perfección organizados en "inefable escala» que todo lo une en "armoniosa proporción" y «felices consonancias» pese a su radical diversidad: "del polluelo del águila en su nido / y el pez al hondo piélago sumido", "del serafín lucido [...] / a la bajeza / del primer punto en que la nada empieza", todos están "a un gran fin siempre ordenados / en su serie asombrosa». Y su contemplación de la sublimidad de la Naturaleza revela una verdad de orden superior y trascendente, de modo que el poema se orienta a la alabanza divina y glorificación del Creador. 
De él [Dios] la dichosa llama

de inefable amor viene

que a cuanto existe encadenado tiene

y vivífica inflama

del globo luminoso, inmensurable,

que un punto luce en el inmenso cielo,

al átomo impalpable,

del gusano que arrastra por el suelo

al ave que su vuelo

sobre las nubes vagarosa tiende

y ve do el rayo asolador se enciende;

y de él tanta armonía,

tanta unión soberana

que no alcanza a sondar la mente humana.

Y por lo sublime cósmico transita también parcialmente la oda VII, Al ser incomprensible de Dios (-1786; ed. 1797; OV, II: p. 871), que ha de ser Lo incomprensible de Dios que menciona Sempere en 1787. El poeta, de nuevo, cuestiona que tal contemplación de lo sublime pueda conducir a conocimiento alguno sin el reconocimiento de la existencia de Dios: allí, "del vil gusano / del sol al carro ardiente, / todo tu ser me anuncia soberano / con lenguaje elocuente», pero cuando «la curiosa razón trepar procura por la naturaleza / ella misma me grita: "Oh, ciego, tente / en tu afán importuno, que entrar en su sagrario no consiente / el Excelso a ninguno" "; y una voz le dice: "Contempla, adora, admira y ruega / y gózame escondido". De modo que el poeta "abismado en tanta maravilla / con miedo reverente / ceso, y humilde inclino la rodilla, / y la devota frente»-de nuevo la rodilla que en 1785 Luzbel no quería doblar ante la silla-.

A la luz de esta relectura cronológica de La noche y la soledad (1780), Vanidad de las quejas del hombre contra su Hacedor (h. 1780-1783), La caída de Luzbel (1784), De las ciencias (-1784), la Epistola I (1785), El hombre fue criado para la virtud, y solo balla su felicidad en practicarla (-1786), la epístola V a Gaspar González de Candamo (1786), la oda XIX, Inmensidad de la Naturaleza y bondad inefable de su Autor (-1785 o -1787), y la oda VII, Al ser incomprensible de Dios (-1785 o -1787), se percibe con nitidez que, lejos de tratarse de una aproximación puntual o de un testimonio anecdótico, la estética de lo sublime ya estaba bien asentada en Meléndez en la década del 80. Aunque, dado que estos poemas permanecieron inéditos o fueron publicados de modo fragmentario y disperso, es en la edición de 1797 cuando se evidencia en la pública República de las Letras españolas, lo que en realidad había madurado durante dos décadas de atenta lectura (1776-) y sostenida escritura $(-1780)^{70}$.

70. La datación de algunas otras obras de la edición de 1797 pudiera ser anterior en unos años, pues el 12 de agosto de 1789 Estala le dice a Forner que Meléndez «está recogiendo sus escritos para 


\section{LA EDICIÓN DE 1797: LAS VERDADES SUBLIMES}

En 1797 se visibilizan todos estos poemas y otros nuevos con el abierto reconocimiento -O reivindicación- del poeta de que la temática central de sus poesías filosóficas y morales, las que se ocupan de "las verdades sublimes de la Moral y de la Religión", es "la bondad de Dios, su benéfica providencia, el orden y armonía del Universo, la inmensa variedad de seres que lo pueblan y hermosean» (OV, I: p. 67), esto es, lo sublime cósmico.

Entonces se publica la oda XVI A las estrellas (ed. 1797; OV, II: pp. 900-901), que resulta más difícil identificar con Los cielos que menciona Sempere. Al modo de La noche y la soledad, el grueso del poema es un viaje cósmico: «¿Do estoy? ¿qué presto vuelo / de alada inteligencia me levanta / desde la tierra vil a los reales / alcázares del cielo?». Ya señalaba Froldi: «Meléndez Valdés si immagina in una vera e propria situazione cosmica: unito a una cometa, egli finge di trascorrere per i cieli a scoprire al di là del nostro gli infiniti mondi della creazione, sempre in cerca del más allá e senza mai trovare l'ultimo termine» ${ }^{71}$.

Esta oda nada gustaba al latinista Juan Tineo Ramírez, sobrino segundo de Jovellanos y académico de la de los Acalófilos, que, en un prólogo para las Poesías sueltas de Moratín que dio a la luz Gómez de Hermosilla, compara A las estrellas con La noche serena de fray Luis ${ }^{72}$. Aunque condenándolo -Tineo dice que Meléndez «era regular y muy de temer»-, condensa con acierto los elementos habituales de lo sublime cósmico, que resultaban demasiado innovadores para el crítico clasicista incluso en 1823, ya en plena ofensiva contra Meléndez, el "prologuista [Quintana] y sus secuaces»:

Afectando un entusiasmo que no sentía, se sube con presto vuelo, sin saber dónde está, a los alcázares del cielo; y al instante manda parar a los soles ardientes (que son los del estío) y a las lámparas eternales, para abismar su vista en luz tan gloriosa. Quid dignum tanto feret hic promissor hiatu? Recorre a su modo todo el firmamento, trepando (verbo muy su favorito, aunque bajo) y nombrando los astros y constelaciones, para ostentar erudición, desea unirse a un cometa (también ardiente) y acompañarle en su carrera rápida, escondiéndose por cien siglos en el giro del tal cometa, para ver, cabe el sol, de dónde viene su llama sempiterna, y qué brazo sostiene colgado al mismo sol. Sublime puerilidad! Ridícula fantasía! Delirio ardiente! [...] ¿Y cómo concluye? Diciendo que las lumbres sagradas arderán siempre y la

\footnotetext{
dejarlos en poder de Jovino para la impresión” (Demerson, Georges. Don Juan Meléndez Valdés y su tiempo, t. I, p. 253); el 6/8/1794 Jovellanos exhorta a Meléndez «a acelerar la nueva edición de sus obras»; el 20/8/1796 está en preparación, pues Jovellanos le aconseja que se la dedique a Godoy; y el 22/9/1796 ya "Meléndez envía la mitad del tomo III de sus Poesías». GMJ, OC, tomo VI, Diario. Ed. José Miguel Caso González y Javier González Santos. Oviedo: IFESXVIII, 1994, p. 623; y GMJ, OC, tomo VII, Diario. Ed. Javier González Santos y M. ${ }^{a}$ Teresa Caso Machicado. Oviedo: IFESXVIII, 1999, p. 573.

71. Froldi, Rinaldo. Un poeta illuminista: Meléndez Valdés, p. 105.

72. Sobre esta cuestión, véase: Gutiérrez Díaz-BERnARDo, Esteban. "Fray Luis de León en Meléndez Valdés». Revista de Estudios Extremeños, 1999, LV, 3, pp. 797-846.
} 
mente del poeta, siguiendo con afán el áureo giro de los astros con alas desmayadas, caerá sin aliento. Era regular, y muy de temer. [...] Véase si en esta su oda $A$ las estrellas fue sublime y no más bien ridículo; véase si fue filósofo y no más antes charlador impertinente; véase si puede sacarse menos partido de un asunto tan digno y tan abundante ${ }^{73}$.

En muchos otros poemas datados en la década del 90 encontraremos lo sublime cósmico, con la particularidad de que ya está imbricado con otros motivos y desarrollado en nuevos contextos. En la elegía VI, La virtud. En la temprana $y$ dolorosa muerte de un hombre de bien, posiblemente escrita en memoria de Palafox (¿1790?; ed. 1797; OV, II: pp. 1022-1027), la cadena de los seres alterna de nuevo hábilmente con la vanitas vanitatis. Si en la primera parte de este peculiar elogio fúnebre se enumeran los «mentidos bienes» que ciegan a los mortales y el desengaño respecto al amor, la belleza, las grandezas y la ambición se expresa literariamente mediante formas barrocas -viene la muerte «en sombra y humo / vidas, triunfos, blasones disipando" y los gozos "Sombra y nada / [...] son del turbulento mundo»-, en la segunda parte del poema la mente del sabio virtuoso emprende el viaje cósmico - «Su mente alada generosa vuela / sobre soles y soles, que sin cuento / rodando pueblan el inmenso espacio»- y la visión desde lo alto redimensiona los afanes y permite advertir la inmensidad sideral, la muchedumbre de soles y luego la cadena de los seres, que se ha transmutado en una ley de amor: si en la primera todos los elementos de la cadena son interdependientes y ninguno puede existir sin el otro, en esta obliga a la fraternidad y la búsqueda del bien común.

Él entre tanto en afecciones tiernas, inmenso cual su Autor, a cuanto existe se derrama solícito, inflamado de esta llama de amor que eterna arde por la infinita creación, dichosa cadena que al gran Ser la nada enlaza. Corre sus milagrosos eslabones del polvo al querubín; y en todos viendo el propio bien en el común librado, más y más vivos sus afectos arden.

73. Lo transcribe, compartiendo la argumentación, Gómez DE Hermosilla, José. Juicio crítico de los principales poetas españoles de la última era. Valencia: Mallén y sobrinos, 1840, tomo I, pp. 182-183. Siempre me ha extrañado tal dureza, considerando los años de exilio compartidos en Montpellier. Del contenido y las intenciones del texto da cuenta el propio Tineo a Moratín, en carta recuperada por PÉrez Magallón, Jesús. "Una carta de Juan Tineo a Leandro Fernández Moratín». Castilla: Estudios de Literatura, 1993, 18, pp. 123-138. 
Sublime es La tempestad (1794; ed. 1797; OV, II: pp. 889-891), que él mismo señala a Llaguno que describe "de un modo nuevo en nuestra poesía" (OV, II: 889) ${ }^{74}$ : los torbellinos violentos del Aquilón, las nubes negras y la niebla se lanzan sobre la selva mientras crece el huracán y la horrible voz del trueno «al Omnipotente anuncia", por lo que el yo poético, a merced de semejante locus borridus, "adora y tiembla", y hasta el ateo y el libertino, "de miedo y horror transidos" reconocen el poder de Jehová, que «imperioso domina» y maneja la tormenta.

D’Ors ha destacado el carácter sublime de la elegía: «tiene, como algunos otros romances de Batilo un arranque paisajístico y descriptivo, con un ambiente sublime típicamente prerromántico (es de 1794); pero en la violencia de la tempestad reconoce el poeta la magnitud terrible del poder divino» ${ }^{75}$. Ciertamente el reconfortante final todo lo resignifica, pues la clemencia divina amaina la tormenta; como señala Froldi: "Suscita terrore e i mortali smarriti lo vedono quasi come un vendicatore terribile delle loro colpe ma poi la tempesta si scioglie in pioggia fecondatrice e allora gli uomini comprendono la provvidenza di Dio e levano inni alla sua gloria: "ya Padre, ya nos indultas / y el iris de paz nos muestras / en señal de la alianza / que has jurado con la tierra" ${ }^{76}$.

Inéditos usos de lo sublime se perciben en 1794 en la epístola VI, El filósofo en el campo (ed. 1797; OV, II: pp. 783-790), donde mientras los sabios «necios /

74. Puede contrastarse la novedad del tratamiento, que básicamente reside en la estética de lo sublime, en comparación con la oda XXVIII, El otoño (1786; ed. 1797; OV, II: pp. 676-679), en cuyo final «ya de occidente silban las tempestades y ya el cielo, / de tiniebla inclemente / cubierto, el desconsuelo / del aterido invierno anuncia el vuelo»; y con la oda XXVII, En una salida de la corte (¿1784?; ed. 1797; OV, II: pp. 675-676), en que «en negras nubes / encapotado el cielo / el rápido huracán revuelve el suelo. / El blando otoño se amedrenta y cede / al invierno sañudo, que entre nieblas / alza su frente umbría / por la enriscada cumbre del Fuenfría", mientras "cesan mudas las aves, largas lluvias / inundan los collados». En su final, no hay restitución alguna del orden: «en el sepulcro umbrío / polvo y nada entraré, sin que más deje / ¡oh, amargo desconsuelo! / que un nombre vano y lágrimas al suelo».

75. D'Ors, Miguel. Más virutas de taller [2004-2009]. Valencina de la Concepción: Los papeles del Sitio, 2010, pp. 123-132; cita en p. 126.

76. Froldi, Rinaldo. Un poeta illuminista: Meléndez Valdés, pp. 99-100. Por correlación temática, cabe compararla con la oda anacreóntica LVI (1801-1806; ed. 1820; OV, I: pp. 137-138). Aunque en este caso es Después de una tempestad, el yo poético también está atónito y admira la Naturaleza: «Oh, con cuánta delicia, / pasada la tormenta, / en ver el horizonte, / mis ojos se recrean! / ¡Con qué inquietud tan viva / gozarlo todo anhelan, / y su círculo inmenso / atónitos rodean! / De encapotadas nubes / allí un grupo semeja / de mal unidas rocas / una empinada sierra; / recamando sus cimas / las ardientes centellas / que, del sol con las sombras, / más fúlgidas chispean; / y a sus rayos huyendo, / ya cual humo deshechas, / a lóbrego occidente / presurosas las nieblas. [...] Mientras ciega mi mente / de ver tantas bellezas, / en lugar de cantarlas, / ni a admirarlas acierta». Como ya subrayaba Froldi: «il poeta è l'osservatore, posto al centro di una scena meravigliosa ch'egli descrive minutamente, ma con l'animo sospeso, sentendosi inferiore, incapace di rendere in verso tutto quanto i suoi occhi scorgono", actitud típica de la estética sublime, no siempre terrible (p. 59). Aborda estas cuestiones también M. Raillard, que concluye que "The deist framework is hard to miss; Meléndez closes the poem with a recapitulation of God's function and identity within a universe suffused by natural religion" (RAILlARD, Matthieu P. "Deism, the Sublime and the Formulation of Early Romanticism in Juan Meléndez Valdés and José de Cadalso», p. 143). 
tu inescrutable ser definir osan / en aulas vocingleras», el labrador contempla "la hoguera inmensa de ese sol, tu imagen", "del vago cielo en la extensión se pierde», disfruta el viento, el agua y la sombra de un árbol, y ante la Naturaleza comprende su fin último: «en todo / con silencio humilde / te conoce, te adora religioso. / ¿Y estos miramos con desdén?». Aquí lo sublime, la capacidad del labrador para percibirlo, funciona como uno de los elementos del argumentario en defensa de esta clase social, "la clase / primera del Estado, la más útil, / la más honrada".

$\mathrm{Y}$ al año siguiente, lo sublime servirá de ensalzamiento del Príncipe de la Paz en la epístola I (1795; ed. 1797; OV, II: pp. 761-763), en cuyo final Meléndez deifica a Godoy - "la divina / esencia semejando, venturoso / sobre las almas por su bien domina»- y lleva el paralelo al extremo comparando el poder de quien rige la Naturaleza inmensa y ordenada, en términos de lo sublime, y a los súbditos: "Y cual se rige en orden misterioso / este inmenso universo y blandamente / se acuerda y gira en círculo armonioso: / [...] todo concurre a la común ventura / y ostenta del gran Ser el poderío, / así un sabio ministro el bien procura / universal al pueblo confiado / a sus luces y próvida ternura".

Las trayectorias de ambos poemas se cruzarán en 1797 en la epístola VII a Godoy (1797; OV, II: pp. 790-796). Ahora la formación que el labrador alcanzará gracias al proyecto del Semanario de Agricultura le permitirá comprender verdaderamente lo sublime, porque «será su religión más ilustrada; / y el que ora bajo el esplendente cielo, / abrumado de afán, siente y no admira, / cual el buey lento que su arado arrastra, / de su Hacedor la diestra protectora / ostentada doquier [...] / podrá instruido, levantar la frente / llena de gozo a su inefable dueño, / ver en sus obras su bondad inmensa / y en ellas adorarle religioso». Si el conocimiento permite comprender y admirar al Hacedor y su omnipotencia, el propio hecho le hace exclamar: «Gran Dios! ¡qué perspectiva tan sublime / para un alma sensible y generosa!».

El carácter sublime de la retórica de la oda I, El invierno es el tiempo de la meditación (ed. 1797; OV, II: pp. 848-851), ha sido subrayado con acierto por Matthieu Raillard:

His ode El invierno is a veritable catalogue of sublime imagery, among them: «lúgubres días; horrorosos aquilones, míseros mortales, ansias infernales, la muerte en su ominoso fúnebre manto, el relámpago súbito». [...] Meléndez projects the tempus fugit theme through a sublime lens, as the poet's solitude, "Salud, lúgubres días; horrorosos / aquilones, salud» is conjugated with his meditation on the passage of time and the futility of life «espinas solas abrazamos, en inútiles quejas nos perdemos". Life's inexorable march and its unavoidable conclusion, death, are represented by a most sublime image, the sudden lightning strike: «el relámpago súbito, brillante, / que al triste caminante / deslumbra a un tiempo y en tinieblas deja». The natural world is portrayed as desolate and inhospitable, with silence and solitude punctuated only by the "chillido horrendo» of an «ave fúnebre» ${ }^{77}$.

77. Raillard, Matthieu P. "Deism, the Sublime and the Formulation of Early Romanticism in Juan Meléndez Valdés and José de Cadalso", pp. 138-140. 
Ciertamente, la tierra se ha convertido en un locus borridus, en que el invierno se enseñorea de un espacio que asolan los vientos «bramadores / que, despeñados con rabiosa saña, / en silbo horrible derrocar intentan / de su asiento inmutable / la enriscada montaña / y entre sus robles su furor ostentan»; incluso «el cielo, que lumbroso / extática la mente entretenía, / entre importunas nieblas encerrado, / niega su albor al desmayado dían, imposibilitando el disfrute de lo sublime cósmico. Pero este adquiere su sentido último, una vez más, contextualizado en el poema. La enunciación del caos inquieta al yo poético que, "dudando el alma de congojas llena, / tanto desastre y confusión sintiendo, / si el dios del mal el mundo desordena", interroga: "¿Qué es esto, santo Dios? ¿Tu protectora / diestra apartas del orbe?». Si el caos invernaladquiere tintes apocalípticos y conduce a la desesperación es para que resulte proporcionalmente reconfortante la tranquilizadora restauración final del orden, que resulta del reconocimiento del ritmo cíclico de las estaciones, de la estabilidad del cosmos:

Mas no, Padre solícito, yo admiro tu infinita bondad: de este desorden de la naturaleza, del alternado giro del tiempo volador nacer el orden haces del universo, y la belleza.

De tu saber la alteza lo quiso así mandar: siempre florido no a sus seres sin número daría sustento el suelo; en nieves sumergido la vital llama al fin se apagaría. Esta constante variedad sustenta tu gran obra, Señor: [...] de un modo portentoso todos al bien concurren; tú has podido sabio acordarlos; y en vigor perenne, de implacables contrarios combatido, eterno empero el orbe se mantiene. Tú, tú a ordenar bastaste que el ligero viento que hiere horrísono volando mi tranquila morada, y el undoso aguacero que baja entre él las tierras anegando, al julio adornen de su mies dorada. Así su saña airada grato el oído atiende, y en sublime meditación el ánimo embebido, a par que el huracán fragoso gime, se inunda el pecho en gozo más cumplido. Tu rayo, celestial filosofía, 
me alumbre en el abismo misterioso

de maravilla tanta:

muéstrame la armonía

de este gran todo, y su orden milagroso;

y plácido en tus alas me levanta

do extática se encanta

la inquieta vista en el inmenso cielo.

Allí en su luz clarísima embriagado

hallaré el bien que en el lloroso suelo

busqué ciego, de sombras fascinado.

En este volumen publica también Meléndez uno de sus discursos filosóficos más emblemáticos, y sin duda uno de los poemas más acabados sobre lo sublime cósmico en España, donde aparecen plenamente trabadas las imágenes de inmensidad, variedad, orden del universo y cadena de los seres: su extenso discurso III, Orden del universo y cadena admirable de sus seres (1795-1797; OV, II: pp. 1044 y ss. $)^{78}$. De él se había adelantado de forma anónima un fragmento en 1795 en el Semanario de Salamanca, significativamente titulado "Sobre el origen del ateísmo y de los errores de nuestros días» y al pie "Sistema y orden del universo». Meléndez parece ser muy consciente del valor y originalidad del poema en el contexto español, pues pasa a cerrar, junto a los otros dos discursos, la colección de $1820^{79}$.

En las estrofas iniciales, el callado meditador alcanza el conocimiento divino mediante el estudio del universo, pues el orden, esa cadena de inmensos eslabones, exige la existencia de un creador que todo lo concierta. Este esquema, que luego Meléndez ejemplifica minuciosamente, adelanta ya motivos habituales de lo sublime cósmico, como lo "inconcebible» del universo, pues es inmenso y sus entes incontables, y el sentimiento de "desfallecimiento" que dicha visión genera en el espectador, cuya razón permanece «atónita».

¡Desfallece mi espíritu, la alteza de tu ordenada fábrica admirando, oh, inconcebible, oh, gran naturaleza! Los ojos subo al cielo, y rutilando

78. Lo analizamos detenidamente en Nuevos mundos poéticos. La poesía filosófica de la Ilustración, pp. 257-267. La Oración de Jovellanos de 1799 guarda notable hilazón con este discurso, que Jovellanos conocía bien, por estarle dedicado. En la tertulia gijonesa leen «el sublime Discurso III de Meléndez» el 2/3/1797 (GMJ, OC, VII: pp. 685).

79. Estas operaciones siempre son de interés. Sobre estos movimientos y sus sentidos, en relación al índice manuscrito que dejó el propio Meléndez para la edición de 1820, ha de consultarse LAMA, Miguel Ángel. «La ordenación de las Poesías de Meléndez Valdés». En Juan Meléndez Valdés y su tiempo (1754-1817). Ed. Jesús Cañas Murillo, Miguel Ángel Lama, José Roso Díaz. Mérida: Editora Regional, 2005, pp. 183-200. Los índices de las tres ediciones son transcritos y analizados por Rodríguez Moñino en su edición: Rodríguez-MoÑino, A. (ed.). Juan Meléndez Valdés. Poesías inéditas. Madrid: RAE, 1954. Los de estos poemas se hallan en pp. 58-61 y 76-77. 
soles sin cuento en tronos de oro veo

sobre mi frente atónita girando.

Concertado

todo está; el orbe una cadena ofrece

de inmensos eslabones al callado

meditador: estúdiala, y humilla

la frente ante el Señor que la ha formado.

Si la advertencia "Doquier te vuelvas, por doquier que fueres, / un orden has de hallar; pero abarcarle / jamás, jamás con la razón esperes» insiste en señalar los límites del conocimiento científico, la "alada» inteligencia lo conmina a alzar la vista para admirar las maravillas divinas; pero esta visión primera -de abajo hacia arriba- solo corrobora la sensación inicial de arrobamiento ante lo multitudinario de la creación -en la «inmensa esfera", «qué de globos ardientes! ¡qué raudales, / qué océanos de luz! iqué de ostentosos / soles!»- pues no se encuentra la causa de tanta variedad. "¿Al cielo volar quieres?» interroga la inteligencia, y comienza el viaje cósmico tan caro a la poesía del siglo XviII que estructura el discurso y en que se adquiere un conocimiento de orden superior: la mirada a vista de pájaro y en perspectiva revela el orden último del universo, la newtoniana ley de atracción universal que todo lo encadena como una lazada divina -desde los lejanos y fugaces cometas a las partículas invisibles-:

Yo vi entonces el cielo encadenado, y alcancé a computar por qué camina en torno el sol Saturno tan pausado. ¡Oh, atracción! ¡oh, lazada peregrina con que la inmensa creación aprieta del sumo Dios la voluntad divina!

Tú del crinado rápido cometa al átomo sutil el móvil eres, la ley que firme ser a ser sujeta.

En las estrofas siguientes la cadena se concreta en el recorrido de las aguas -que van del mar a la atmósfera, los ríos, las aguas subterráneas, los lagos, las fuentes, hasta alimentar árboles y congelarse en los montes-, en la bóveda celeste, en que el sol preside en su trono a los planetas mientras «de otro sistema este es columna", y en una cadena infinita que conduce al origen: "y otro sobre otro sin mudanza alguna / hasta llegar al Numen de quien tiene / su ser el universo". Ante tal revelación el yo poético exclama:

¡Oh, inmensa sucesión, a que no alcanza

saber mortal! ¡Oh, variedad estable, grande aliento a la tímida esperanza! Sí, sí, Jovino: el Bueno, el Inmutable, 
el Poderoso, el Sabio cuanto hiciera, lo enlazó en nudo y orden inefable. Todo es unión: la parte más ligera de impalpable materia al sol luciente sostiene y carga en su inexhausta hoguera. Nada hay que no sea efecto y juntamente causa no sea, igual el vil insecto cabe el gran Dueño al querubín ferviente: en su inmenso saber no hay más perfecto. Vio, quiso, obró; y a cada ser ha dado virtud con relación a su alto objeto. Esas mínimas formas que ha creado al parecer sin fin, ruedas son leves que altamente en las otras ha engastado. Ésa que en nada tu ignorancia cuenta, en nudo firme a otra mayor se unía; y otra aun mayor sobre las dos se asienta.

La inmensidad y el orden que subyacen bajo el aparente caos vienen a demostrar la existencia divina, que todo «lo enlazó en nudo y orden inefable». Y la omnipotencia del creador se ve subrayada por el tópico de la totalidad, pues el nudo ata lo más pequeño, "la parte más ligera / de impalpable materia", y lo más grandioso, el sol; lo más insignificante, el insecto, y lo más próximo a Dios, el querubín. Descrita la relación del ámbito acuático y el celeste y manteniendo el recurso del vuelo, Meléndez torna a la tierra y ensaya una cadena de los seres, desde la «materia inánime» al reino animal -«si en su estupendo / orden, su graduación, sus perfecciones / un religioso horror no estás sintiendo"- para describir los "trabados eslabones" que unen seres tan dispares como el insecto y el hombre - Este es el hombre, en su inmortal aliento / imagen de su Autor, que la estructura / del orbe abarca en su hondo pensamiento»-, pasando por crustáceos, reptiles, peces, aves, mamíferos... mediante la expresión reiterada "de este a este otro» que marca la unión pese a alguna característica dispar entre ellos -«índole, color, grandeza, / pluma, órganos, fuerzas, voz»-.

Las últimas estrofas del poema, las publicadas en la prensa, condensan los elementos de la cadena de los seres, pero el carácter inmensurable del universo e incontable de los seres, la aparente disparidad y su oculta unión mediante eslabones se orientan a la alabanza divina -de ahí la referencia al ateísmo en el título de la versión del Semanario de Salamanca-. Tal consigue mediante la cascada de interrogaciones retóricas, que se precipitan en el cierre para delimitar las posibilidades del conocimiento científico y volcar el tópico definitivamente hacia el reconocimiento de que la existencia del orden oculto implica la de un creador; y su omnipotencia, la posible existencia de otros mundos habitados. Creo que la hipótesis de que exista vida extraterrestre -ya explicitada en Vanidad de las quejas del hombre contra su Hacedor: "y los que el globo de Saturno moran / tan lejos como tú miran 
al cielo» - es el recto sentido del final del poema: no puede ser corroborada por la razón, pero sí supuesta por la esperanza.

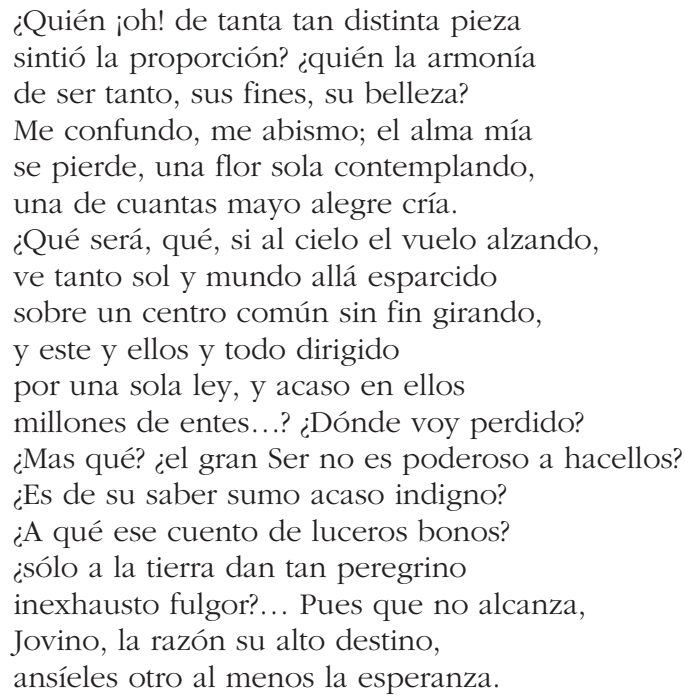

Algunas partes de este discurso III aparecen condensadas en la oda III, $L a$ presencia de Dios (ed. 1797; OV, II: pp. 854-856). Si en su principio «Doquiera que los ojos / inquieto torno en cuidadoso anhelo, / allí gran Dios, presente / atónito mi espíritu te siente», luego hierbas, montes, viento y sol "me claman que en la llama / brillas del sol» y que sobre el viento "cruzas del occidente hasta la aurora». Y después pasa ya a desarrollar en dos series la idea de que "Tu inmensidad lo llena / todo, Señor, y más», para concretar mediante los opuestos su omnipresencia: "del invisible / insecto al elefante / del átomo al cometa rutilante», y, finalmente, del átomo y el "gusanillo / que en el vil lodo mora» al "ángel puro que tu lumbre adora». La percepción de esa existencia superior que es razón de lo más diverso motiva un "religioso miedo"-antes un «religioso horror»-, que no es difícil identificar con la experiencia sublime y que se soluciona con el reconocimiento de Dios, que «en este misterioso / silencio mora»; y también implica la fraternal noción final de que "todos tus hijos somos: / el tártaro, el lapón, el indio rudo / el tostado africano, / es un hombre, es tu imagen y es mi hermano".

Lo sublime reaparece tangencialmente en la oda IV, A la verdad (ed. 1797; OV, II: p. 857), donde esta diosa avala la existencia de "cuanto en su instable / inmensidad el universo ostenta / o al Altísimo en gloria se presenta», pues «en su mente inefable / tú el prototipo fuiste / a cuya norma celestial redujo / cuanto después su infinidad produjo». 
Y en la oda XIII, El mediodía (ed. 1797; OV, II: pp. 642-644), donde tanto locus amoenus como locus eremus son espacios propicios a la reflexión sublime: "Todo es silencio y paz». Si en el primero "los ojos alzando embebecido / a la esplendente esfera, seguir anhelo, en su extensión perdido / del sol la ardua carrera", también «a lo lejos su enriscada cumbre / descuella la alta sierra / que recamada de fulgente lumbre / el horizonte cierra»; y en las "lóbregas grutas... joh, sagrado / retiro deleitoso! / En ti solo mi espíritu aquejado / halla calma y reposo ${ }^{80}$. En su complementariedad ambos locus representan un todo, que es demostración de la majestuosidad de la Naturaleza, porque, como concluye la oda, "Todo embriaga en celestial contento / el tierno pecho mío; / y en tu abismo, inmortal Naturaleza, / olvidado y seguro, / tu augusta majestad y tu belleza / feliz cantar procuro" -en este caso, no se produce el giro final hacia lo divino- ${ }^{81}$.

\section{1797-1815. EL LENGUAJE SUBLIME DE LA MORAL Y LA FILOSOFÍA}

Si en la edición de 1797 lo sublime cósmico irrumpe con fuerza, Meléndez sigue manejando esta estética hasta el final de su prolongada trayectoria poética, como reflejan los nuevos poemas recogidos en la edición póstuma de 1820. En su prólogo de 1815 señalaba abiertamente de nuevo el autor, ya pensando en la posteridad, que "amante de las musas españolas, he procurado ataviarlas acaso con más gusto y aliño que las hallé vestidas, y hacerlas hablar el lenguaje sublime de la moral y la filosofía» (OV, I: p. 61).

Como es casi imposible datar los nuevos poemas más allá de la inclusión en el índice de 1814, cabe comenzar por A un lucero porque, íntegramente conformada por la imaginería de lo sublime cósmico, queda situada en la edición de

80. Del mismo modo sucederá en la oda XXXII, Que la felicidad está en nosotros mismos (-1814; ed. 1820; OV, II: pp. 686-688), donde la "providente Natura" ostenta su hermosura en una variada gama de placeres; escoge, le dice a Julio, entre el viento bullente, las flores que embelesan, el trino de las aves, y, junto a todos los elementos del locus amoenus, señala: "hasta en la noche oscura / el sin fin que en su velo / arde de luces y tachona el cielo, / del sol mismo emulando la hermosura, / si bien sabes mirarlo, todo alegrarte puede».

81. Raillard ha subrayado la estructura binaria de la oda XXI, A la esperanza (-1814; ed. 1820; OV, II: pp. 656-657): «Meléndez uses a binary structure to provide contrast between despair and hope, and constructs this opposition using Burkean aesthetics, with the sublime equating despair, and the beautiful underscoring the deist tone with which he concludes the poem. [...] The message is unambiguous and hopeful, and our poet uses a contrastive sublime/beautiful structure to portray the equally binary despair-versus-hope deist equation» (RAIllard, Matthieu P. "Deism, the Sublime and the Formulation of Early Romanticism in Juan Meléndez Valdés and José de Cadalso", pp. 142-143). Efectivamente, en el inicio el yo poético se ve rodeado de un bando de furias que gritan mientras «Lóbrega noche, pavoroso trueno / de airado rayo agitadora llama, / ruedan en torno de mi triste frente, / de horror helada»; pero lo sublime inicial se ve matizado pues, como subraya el título, el cuerpo del poema es la súplica a la hija del cielo de que no lo abandone, y tal espera que suceda. 
1820 en segundo lugar (-1814; ed. 1820; OV, II: pp. 852-854), de modo que lo sublime abre y cierra la colección.

En su inicio, la contemplación de la estrella en la "bóveda infinita» "entre tantos miles / en que atónito vacila el espíritu" provoca el «ejercicio de la mente», que se demora en los "inexhaustos fuegos", en "cuánto es rica / la vena de luz", en cómo «en órbitas bien distintas / hacen sus largos caminos / van, vuelven, nacen, se eclipsan / pero sin jamás tocarse / siempre en acorde medida / desde que fue el tiempo".

Esta parte introductoria desemboca en el elogio de los astrónomos que los contemplan «embriagados en su belleza divina» y llegaron "con atrevida / profunda mente a alcanzarlos / en la inmensidad do huían». Como el conocimiento supone dominio y los astrónomos han desvelado las reglas que rigen el cosmos, Copérnico y Newton son deificados ${ }^{82}$ : «a un ángel semejante / sentó un mortal en su silla / inmóvil al sol, que en torno / rodar sus planetas mira»; y «el divino Newton / alzándose del empíreo / do el gran Ser más alto habita / de él mismo aprendió felice / la admirable ley que liga / al universo, sus fuerzas / en nudo eterno equilibra / y hace en el éter inmenso / do sol tanto precipita / que pugnando siempre huirlo, / siempre un rumbo mismo sigan». Y la «humanal osadía» del conocimiento, lejos de implicar el tradicional castigo por bybris, conduce a la comprensión profunda del misterio: «el inapelable coro de estrellas / ya descifrado a los hombres, / de beldad más peregrina / fue a sus ojos». La fascinación por la comprensión armónica del universo desemboca, una vez más, en la hipótesis de la pluralidad de los mundos, que en este caso vira hacia lo utópico: "¿Sois los soles de otras tierras, / do en más plácida armonía / que aquí, sus débiles hijos / vivan sin odios ni envidias?». Finalmente, la mente "atónita admira, / más y más que admirar halla, / y más cuanto más medita» y el poema se cierra de un modo un tanto retórico y artificioso, con la llegada de la mañana, que oculta la estrella.

El espectáculo sublime de los cielos se revela con especial intensidad en la oda XVIII, La aurora boreal (-1814; ed. 1820; OV, II: pp. 651-652), donde el poeta insta a la temerosa Lice a disfrutar de un fenómeno que la aterra: «el vistoso espectáculo que ofrece / un nuevo día al suelo / ardiendo hermoso el ámbito del cielo». Los espectadores contemplan la enérgica potencia del fenómeno extraño e indómito - «esas ardientes flechas, esa hoguera, / viva, agitada, que en su lumbre inflama / del aire el gran vacío, rompiendo de la niebla el cerco umbrío, / tantos grupos y piélagos de fuego / que hirviendo bullen, la riqueza suma / de matices y albores / que del iris apocan los primores»-; un espectáculo cuyo poder se manifiesta, una vez más, en la variedad: «viérasla allí de mil y mil maneras / el cielo esclarecer: ora lanzarse / en rápido torrente, / ora alzar leda la rosada frente / [...] si

82. No me detengo ahora en la vinculación de este recurso de la divinización con lo sublime. Lo he analizado en Nuevos mundos poéticos. La poesía filosófica de la Ilustración, pp. 206-239; para Meléndez Valdés, pp. 229-233. 
no se agita en turbulentos rayos / que aquí y allá flamígeros discurren / ahogando sus centellas / el fuego brillador de las estrellas, / o en marco inmenso se derrama y sube / hasta el cénit». Aunque tal visión aterra a Lice, el experimentado contemplador de los cielos la tranquiliza: «No temas, pues, las ráfagas ardientes, / ni rayos tantos, ni vistosos juegos / como en sus pasos forma"; y el prodigio se resuelve al ser comprendido: "son otra nueva aurora, que del polo / corriendo boreal con sus reflejos / el horizonte dora» con "infinita copia de luz». En realidad, la aurora boreal es, finalmente, el triunfo de la luz sobre la noche «llenando de alegría / su eterno hielo y su tiniebla umbría", "rigiendo augusta con luciente cetro / el yerto polo y páramos sombríos / do en toda su grandeza / su majestad se ostenta y su belleza». Cabe reseñar que es uno de los pocos poemas que se mantiene en una órbita laica; solo "el lapón rudo extático contempla» la aurora atribuyéndole un cariz religioso: "acata entre ella a sus paternos manes», pero el poeta no reconduce tal maravilla hacia el ámbito de la teodicea.

La oposición de lo sublime cósmico con un remozado menosprecio de corte y alabanza de aldea estructura la oda XXIX, titulada significativamente La meditación (-1814; ed. 1820; OV, II: pp. 950-953) ${ }^{83}$, en que se enfrentan diversos ideales vitales: si la guerra, la ambición, la fama, el deleite y la pasión solo conducen al hombre a delirios errados, el estudio de la Naturaleza es el camino hacia la virtud, pues gracias a él se advierte la cadena de los seres que permite el reconocimiento de Dios como ordenador del todo, de la «infinidad de seres», del "sin cuento de soles», del «inmensurable espacio»...

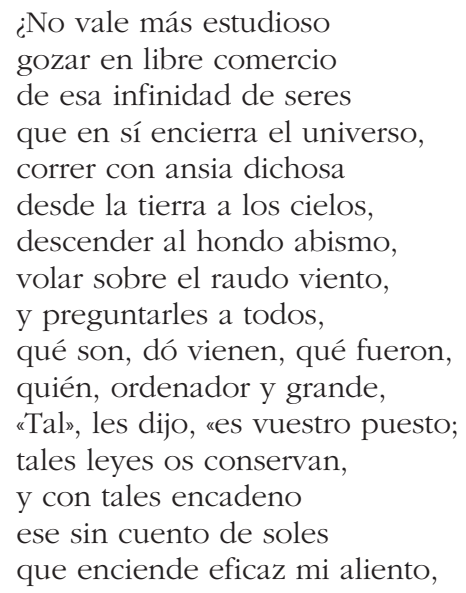

83. Una relación similar entre ambos tópicos se encuentra en la epístola IX, a Plácido Ugena (1802-1808; ed. 1820; OV, II: p. 808), donde se refiere a su desgracia y su parcial rehabilitación esperando un retiro en que desearía dedicarse a "la sublime celestial Sofía" y "con solícito afán la noche, el día / para elevarme hasta su excelso Dueño / su obra inmensa sagaz estudiaría». 
del inmensurable espacio

velocísimos corriendo

las sendas que les marcara

con mi omnipotente dedo?».

Por eso se insta a sí mismo a emprender el viaje cósmico: «al Excelso / por el éter infinito / trepa con alas de fuego", para reconocer "esas bóvedas inmensas / ese sin fin de luceros / que sobre mi frente brillan, / siglos y siglos ardiendo" y que pregonan «en el orden estupendo / con que los misterios ruedan / la mano que los ha puesto"; y para comprender los secretos de Natura, como "ese crecer cuanto vive, / y el insoldable misterio / de encerrarse en uno solo / millones de seres nuevos". Esta vinculación entre el estudio científico y la alabanza divina queda condensada, como es habitual, al final del poema, en los versos en que se exhorta de nuevo a esta contemplación, calificada de "ambición sublime»: "con noble empeño / del ser por la inmensa escala / de este Ser llégate al centro».

Lo sublime está presente también, lógicamente en La creación o la obra de los seis dias (1801-1814; ed. 1820; OV, II: pp. 957-970) ${ }^{84}$, oda cuyo planteamiento puede preverse a tenor de los últimos versos, donde el yo poético admira rendido al "Ordenador de mundos soberano".

Sobre los cielos giro,

cruzo del mar las bóvedas saladas,

de las heladas zonas a la ardiente;

y todo es un portento.

¡Sublime creación! Al bosquejarte,

falta al numen atónito el aliento;

jamás la mente acaba de admirarte.

A estos versos había precedido en otros 500 el viaje cósmico - ¿¿Dónde la mente en tus etéreas alas / se encumbra, el viento impávida surcando, / inspiración divina?»-, que le eleva hasta el Sol, para llegar a Urano, dejar atrás a "cuanto por la inmensa esfera / arde sol claro al lente inaccesible», y llegar a "tocar los últimos confines / del reino de la luz", donde encuentra al soberano por cuyo «excelso mandamiento / esta máquina inmensa fue ordenada», donde "velado / en majestad gloriosa / yace el Señor sentado» - anotaban Polt y Demerson, con toda la razón: "No nos explicamos esta contradicción" (OV, II: p. 958)-.

Como en la versión del Génesis, la creación comienza por la luz -«Los gérmenes primeros / por la fecunda voz a unirse empiezan, / ciegos girando en vértices

84. Polt y Demerson señalan como referencias el Génesis y el Paraíso perdido de Milton, tanto directamente como a través del oratorio de Haydn, La creación del mundo, de cuya traducción francesa por Segur (1800) se conserva copia autógrafa de Batilo (OV, II: p. 957). Para un análisis de este oratorio en relación con la pastoral divina y lo sublime cósmico puede consultarse KRAMER, Lawrence. «Recalling the sublime: the logic of creation in Haydn's Creation». Eighteenth-Century Music, 2009, 6.1, pp. 41-57. 
ligeros / que en su incesante vuelo se tropiezan»-; y luego se dividen las aguas y se extiende el firmamento, ante lo que exclama: "iQué armonioso conjunto / de eterno albor que en torno lo ilumina, / orden, belleza, variedá [sic] extremada!». Sublime es también el espectáculo de la creación del mar: «Él rueda en su hondo abismo y se conmueve; / llega, huye, torna, apártase; y bramando / de hórridos vientos lleno, / las rocas desgarrando, / ya el cielo en sierras de agua a herir se atreve, / ya su azul pinta plácido en su seno». Como sublime será la puesta en marcha del cosmos, cuando los astros «a dar su vuelta eterna, silenciosa, / cual ordenado ejército empezaron", unos astros que la visión en perspectiva revela infinitos: «en su inmóvil quicial el Polo viera / miles en derredor de astros brillantes, / que contar solo su Hacedor pudiera». Y también es sublime la escena de los habitantes del mar: si «el trémalo falaz su presto fuego / eléctrico despide», mansas focas saltan y remonta el salmón para desovar, ve «el glacial polo a la ballena fiera / señora de las olas", y navega el "tiburón aleve / con el manso delfín», porque, en esta apoteosis de variedad «Todo es vida y acción".

Destaca, por último, en esta edición de 1820, esa suerte de autobiografía intelectual del tiempo de los destierros que es Mis desengaños (¿1798-1808?; ed. 1820; OV, I: pp. 406-408). Meléndez establece en este romance XLI una trayectoria que va de la poesía amorosa a la filosófica para conducirlo a la fiscalía, y su dedicación a la poesía filosófica es precisamente representada por la imagen del viaje cósmico. "Ansioso / de otros bienes, con altivo / pensamiento de las ciencias / sondar osé los abismos", y, movido por los "tesoros peregrinos" de la "augusta filosofía", fue su «incesante estudio» la Naturaleza, y fue visto, bien "mudo extático en mis libros", o bien o bien lanzado al viaje cósmico, para

perderme en vuelo atrevido
de la nada y del espacio
por el inmenso vacío,
hasta topar con el trono
que en las cumbres del Olimpo
asentó Aquel que modera
la eternidad y los siglos.
$\quad \ldots$
Quise apurar de los seres
las esencias, el destino
que a ella señalarles plugo
en este todo infinito,
de dó su hoguera alimenta
el claro sol, qué principio
concita el plácido viento
en rápidos torbellinos,
por qué el inmenso Oceano
va, y huye, y torna impelido
de una ley siempre constante


de la playa a sus dominios, por qué... Vendados los ojos corrí, cual errado el tino da el viandante en negra noche de uno en otro precipicio.

Lo sublime no ha conducido aquí a ningún tranquilizador conocimiento trascendente: el yo poético no halla respuestas y solo consigue «mil tétricos desvaríos: / dudar, cavilar, y nada / de cierto; vago, perdido / de encontradas opiniones / por un ciego laberinto, / sin alcanzar quién me diese / de Ariadna el feliz hilo / para seguirle, o me alzase, / Natura, tu velo umbrío".

Esta trayectoria poética y vital que de sí mismo dibuja Meléndez es aproximada a la de la elegía III, De mi vida (1789-1794; ed. 1797; OC, II: pp. 1011-1014): "Amé, y hallé dolor; volví el deseo / a las ciencias, creyendo que serían / al alma enferma saludable empleo. / Las ciencias me burlaron, me ofrecían / remedios que mis llagas irritaban, / y a la hidalga razón grillos ponían. / Dejélas, y corrí do me llamaban / la oficiosa ambición y los honores».

Pero no cabe extraer de este peculiar giro mayores conclusiones. Por un lado, todas las actividades engarzadas - poeta amoroso, poeta filósofo, fiscalía- se convierten en vanidades y fracasos; por otro, conducen a un otro reconfortante final, el que proporciona la vida retirada en el campo y la búsqueda de la virtud; por último, como hemos visto, exactamente lo contrario ha planteado en muchos otros poemas contemporáneos: en este mismo volumen de 1820, en la oda anacreóntica XL, De mi vida en la aldea (-1814; 1820; OC, II: p. 118), disfruta del retiro nocturno en que puede "su manto de luceros / medir sus direcciones / con ojos más atentos / volviéndome a mis libros, do atónito contemplo / la ley que portentosa / gobierna el universo".

Al fin y al cabo, la datación de los poemas demuestra que tal trayectoria poética no es más que un exitoso relato ${ }^{85}$. Fue desmontado por el paciente recuento de William Colford, que demostró cómo Meléndez fue incorporando anacreónticas en las sucesivas ediciones, y es desmentido de nuevo por la cronología de los poemas filosóficos. Si en la edición de 1820 se habían sumado 8 odas filosóficas y sagradas, en 5 de ellas se percibe la presencia de lo sublime cósmico.

Termina aquí este largo recorrido por lo sublime cósmico de la mano de Meléndez, en que finalmente se ha constatado la presencia de lo sublime cósmico en 25 extensos poemas: 9 datados entre 1780 y 1785-1787, 11 datados entre 1787 y 1797, y estos últimos 5, incluidos en la edición de 1820. Cabe señalar que en la edición de 1797 son 22 las definidas como "odas filosóficas y sagradas» y 8 las que se incluyen en la edición de 1820 -cuatro se publican con posterioridad-. Creo

85. Sobre la representación de sí mismo como poeta y literato, puede consultarse: OLAY VALDÉs, Rodrigo. "Juan Meléndez Valdés: una carrera literaria en los circuitos del poder». En LORENZO ÁLVAREZ, Elena de (coord.). Ser autor en el siglo XVIII. Gijón: Ediciones Trea, 2017, pp. 347-371. 
que esa proporción de 25 sobre 34 y su sostenida presencia desde 1780 y 1814 alcanza para aquilatar hasta qué punto lo sublime cósmico que se asocia con la modernidad europea signa la poesía filosófica de Meléndez, el poeta filósofo por excelencia -con permiso de Trigueros- del siglo XVIII español.

\section{REFLEXIONES FINALES: LO SUBLIME, EL DEÍSMO Y EL PRERROMANTICISMO}

Por un lado, el volumen de este corpus de lecturas y poemas en que lo sublime se vuelve a lo divino casi obliga a volver a plantear la cuestión de la religión y Meléndez. Su deísmo se convierte en eje central del estudio de Matthieu Raillard, quien lo concibe como «a reconciliation of reason and God, and for Spanish authors of this era deism represented a rational alternative to the intransigence and fanaticism of religion ${ }^{86}$. Es cuestión debatida hace décadas. Demerson defendía su ortodoxia, reconocía cierto deísmo y matizaba, creo que de forma un tanto desvaída, que se trataría de un deísmo sentimental en que la existencia de Dios no se deduce, sino que se intuye a través de las bellezas de la Naturaleza ${ }^{87}$. Rinaldo Froldi apostaba más decididamente por el deísmo, subrayando, además, las implicaciones religioso-políticas que la manifestación pública de lo que se asociaba con el deísmo conllevaba entonces en España:

In effetti alla base dell'entusiasmo euforico (senza dubbio costruttivo) di cui s'è detto, stava il compromesso con l'idea di un Dio che dell'ordine razionale della natura era il creatore e il custode, oppure quell'ordine stesso era semplicemente postulato, presupposto cioè e non dimostrato, lasciando la porta aperta a soluzioni panteistiche. [...] La natura, legata da precisi rapporti di causa ed effetto nei suoi molteplici aspetti, è spiegata con il riconoscimento di una Causa prima. Siamo in presenza di quella concezione deistica tanto diffusa nel pensiero del secolo. [...] Questo accostamento a Pope e al deismo ha il chiaro significato di un distacco dalla fede cattolica in cui era stato educato, distacco che sostanzialmente, pur tra le molteplici cautele suggerite dalle circostanze, durerà tutta la vita. Dio compare frequentemente nella poesia di Meléndez Valdés ma non ha mai i caratteri del dio cattolico. S'osservi che nelle sue poesie non e mai nominato Cristo e non c'è cenno alcuno della Madonna e dei Santi, dei miracoli e dei sacramenti della fede cattolica. Gli attributi con cui si designa Dio sono: Primero Ser, Señor, Jehová, Padre, Ser eterno, Altísimo, Hacedor, Ser infinito, Fuerte, Omnipotente, Bienhechor, Ordenador, Numen, Bueno, Inmutable, Sabio, Poderoso, Todopoderoso, Conservador, Causa primera, Providencia. Si tratta evidentemente d'appellativi che s'addicono all'Ente primo dei deisti, anche se in parte ripresi dalla tradizione biblica, senza però che compaia un termine specificamente cattolico, riferibile a Cristo, come per esempio Salvatore, Redentore, ecc ${ }^{88}$.

86. RaIllarD, Matthieu P. «Deism, the Sublime and the Formulation of Early Romanticism in Juan Meléndez Valdés and José de Cadalso", p. 140.

87. Demerson, Georges. Don Juan Meléndez Valdés y su tiempo, t. II, pp. 247-252.

88. Froldi, Rinaldo. Un poeta illuminista: Meléndez Valdés, pp. 87-94. 
Más recientemente, ha dedicado Miguel d'Ors algunas interesantes virutas de taller a cuestionar el deísmo de Meléndez, argumentando que el dios deísta no podría intervenir en la Naturaleza una vez creada, como sucede en sus poemas ${ }^{89}$. Sea más o menos ortodoxo su catolicismo y su deísmo, el propio D’Ors señala con acierto que no nos encontramos ante tratados de teología sino ante obras literarias.

Compartiendo tal enfoque, que deslinda literatura y dogma, y al poeta y al hombre, coincidiremos con Nigel Glendinning en que nos encontramos ante «un poeta optimista y religioso ${ }^{90}$. Avanzando en estos ejes, podríamos matizar que la religión funciona en los poemas más que como un conjunto de dogmas, normas y prácticas, en su sentido etimológico, como lo que liga al hombre con la trascendencia, proporcionándole una reconfortante respuesta frente a lo inextricable; y que la entreveración de lo sublime y lo religioso es signo de los tiempos, pues es lo que hace, como decía el poeta del labrador, que sea "su religión más ilustrada" (1797; OV, II: pp. 790-796). También podríamos matizar, reubicando la cuestión en términos literarios, que, como bien muestra su reiteración a lo largo de décadas, el teísmo funciona codificado conforme a una pautada poética de trabados elementos retóricos, que, además, como hemos visto, no solo alienta en fuentes deístas, sino también en la tradición teológico-científica de la teodicea cristiana que recurre a la Naturaleza como demostración de la existencia de la divinidad.

Por otro lado, parecemos abocados también a plantear la cuestión del posible carácter prerromántico o romántico de lo sublime. James Mandrell ha situado La noche y la soledad en una serie formada por Las ruinas de Torrepalma, La escuela del sepulcro de Cienfuegos y El estudiante de Salamanca de Espronceda, serie que permitiría "entender las diferencias entre los neoclásicos y los románticos en su reacción a, y en relación con, la cuestión de la muerte, del fin de cada hombre, y además la posibilidad de ver lo que los une, la búsqueda de lo que llamara Bécquer en sus Rimas la "desconocida esencia"». Precisamente por asociar lo sublime con el Romanticismo y entender que Meléndez huye de lo sublime al rechazar la soledad y la trascendencia -hipótesis que no compartimos-, Mandrell considera que "al caer en el estilo sublime, huye de lo propiamente sublime» y que, por tanto, Meléndez está alejado del Romanticismo ("Meléndez Valdées flees the sublime, demonstrating how removed he is from the Romantic view of the world» $)^{91}$. Matthieu Raillard, sin embargo, se refiere a un "Early Romanticism» y razona que "the onset of literary Romanticism in the Spanish eighteenth century was heavily influenced and partially defined by the conjugation or two systems: the aesthetic

89. D'ORs, Miguel. Más virutas de taller [2004-2009], pp. 123-132.

90. GLENDINNING, Nigel. "Influencia de la literatura inglesa en España en el siglo XVIII", p. 80 (también pp. 88, 93, 94). Como hemos visto, las excepciones son contadas: tal giro no se produce en la oda a Cadalso, quizá precisamente por ser inacabada; ni el romance XLI, Mis desengaños, donde en todo caso se recluye en una no menos tópica y reparadora alabanza de aldea.

91. MANDRELL, James. "The Literary Sublime in Spain", pp. 294-313. 
framework of the sublime and the philosphical-religious construct of deism». Aunque uno niega y el otro afirma, ambos autores asocian la presencia de lo sublime en el siglo XVIII con el inicio del Romanticismo ${ }^{92}$.

Estas argumentaciones pueden contextualizarse en el marco del propio debate sobre el prerromanticismo de la poesía del siglo XVIII y del propio Meléndez. En lo que hace a Batilo, su prerromanticismo ya fue formulado por E. Allison Peers en su Historia del movimiento romántico español, y cuestionado por Georges Demerson, quien señalaba que los ejemplos "contradicen las afirmaciones» y encontraba más atinada la vía de William Colford «in the transition from Neoclassicism to Romanticism», considerando que Meléndez «inició en España una de las vías del romanticismon' 93 .

También Joaquín Arce, en su pionero capítulo sobre la "Poesía astral», decía que «esta sensación de infinitud es muestra del sentimiento romántico que se avecina, ya intuida por los mejores poetas ilustrados del mundo sideral, tan sensibles a la armonía del universo, como a su caótico desorden si tal armonía le faltara ${ }^{94}$. Más recientemente, Irene Gómez Castellano, analizando poemas de Meléndez sobre la noche y la luna, vuelve a la idea de que "se mezcla un modo ilustrado y a la vez romántico de enfrentarse al tema de la noche, la luna, las estrellas, y la naturaleza nocturna en general. Un modo casi religioso, pero también científico", reconoce un sentimiento "de arrobamiento ilustrado pero también de duda romántica», y lee las odas nocturnas como "obras-bisagra entre la Ilustración y el Romanticismo" ${ }^{95}$.

$\mathrm{Al}$ margen de los serios cuestionamientos que con el tiempo han realizado de las interpretaciones en clave prerromántica o romántica historiadores como José Miguel Caso González o Jesús Cañas Murillo ${ }^{96}$, la estética de lo sublime cósmico tal como la formula Meléndez condice con una retórica bien asentada ya en los ensayos de Addison de 1712. Es más, según Ernest Tuveson, las nociones de Addison avanzan y solucionan dilemas ya abordados al hilo del concepto de infinito del siglo XVII, que supondría la base de la nueva cosmología, lo que demuestra a través de los textos de Henry More, Newton, Samuel Clarke, Locke y Thomas

92. RaIllard, Matthieu P. "Deism, the Sublime and the Formulation of Early Romanticism in Juan Meléndez Valdés and José de Cadalso", p. 132.

93. Demerson, Georges. Don Juan Meléndez Valdés y su tiempo, t. II, pp. 261-264.

94. ArCE, Joaquín. La poesía del siglo ilustrado. Madrid: Alhambra, 1981, p. 350.

95. Gómez Castellano, Irene. "De lo diurno a lo nocturno en la poesía de Meléndez Valdés». eHumanista, 2012, 22, pp. 252-271.

96. CASO GONZÁLEZ, José Miguel. «Introducción general a la literatura del siglo XVII». En Historia de la literatura española. León: Everest, 1995, pp. 39-41; CAÑAS Murillo, Jesús. «Sobre posbarroquismo y prerromanticismo en la literatura española del siglo XVIII. En Álvarez BARRIENTOS, Joaquín y CHECA Beltrán, José (eds.). El siglo que llaman Ilustrado. Homenaje a Francisco Aguilar Piñal. Madrid: CSIC, 1996, pp. 159-169. 
Burnet, de quien Addison había sido discípulo; y, en última instancia, en el horizonte cultural se percibiría la tradición neoplatónica ${ }^{97}$.

Dado que lo sublime es una categoría filosófica y estética con una tradición que se remonta a Longino y Lucrecio y llega hasta nosotros, con las lógicas mutaciones a que obliga sobrevivir tantos siglos, el encadenamiento de fuentes y la pervivencia secular del concepto - por no decir el propio devenir histórico- aconsejan resituar la cuestión en contexto y razonar en el sentido inverso, interpretando los supuestos elementos prerrománticos de la Ilustración como pervivencia de determinadas nociones, luego recuperadas y resignificadas por el Romanticismo. Como concluye Valeriano Bozal, lo sublime está «más allá y más acá del Romanticismo y el Neoclasicismo que convencionalmente lo reclaman para sí» ${ }^{98}$, porque "lo sublime enlaza con lo neoclásico, no solo con lo romántico». Quizá la visión dicotómica que deslinda razón y sensibilidad, el dominio ilustrado de la Naturaleza y la rendición romántica ante ella, genera una falsa paradoja, porque, como clarifica Eugenio Trías, lo sublime activa «una Idea de la Razón» y «a través del gozoso sentimiento de lo sublime el infinito se hace finito" con lo que "los dualismos entre razón y sensibilidad, moralidad e instinto, número y fenómeno quedan superados en una síntesis unitaria" ${ }^{99}$.

En este sentido, resultan especialmente esclarecedoras las conclusiones de Anne Janowitz, quien, tras analizar los tópicos poéticos del universo sublime en la poesía inglesa, percibe a lo largo del siglo XVIII una pervivencia: "for the poet of the night sky, who looks up, not out, the task is to totalize something that cannot be encompassed: the infinitude of the universe itself"; pero también una transición "from a confident set of assertions about universal coherence, to a more troubled, secular, and psychological representation of the experience of sublimity» ${ }^{100}$.

No es posible aún realizar tal ejercicio para la poesía española del XVIII, porque lógicamente Meléndez no es el único poeta en abordar lo sublime cósmico ${ }^{101}$,

97. Tuveson, Ernest. "Space, deity and the "natural sublime"», pp. 13-19.

98. BOZAL, Valeriano. "Sublime, neoclásico, romántico». En BuRKE, Edmund. Indagación filosófica sobre el origen de nuestras ideas de lo sublime y de lo bello. Murcia: Colegio de Aparejadores y Arquitectos, 1985, pp. 7-37.

99. Trías, Eugenio. Lo bello y lo siniestro. Barcelona: Seix Barral, 1982, p. 24.

100. JANOWITZ, Anne. "What a rich fund of images is treasured up here": Poetic commomplaces of the sublime universe». Studies on Romanticism, 2005, 44.4, pp. 469-492; cita en p. 471.

101. Ya se ha mencionado la epístola V de Jovino a Batilo; y cabe poner sobre la mesa la epístola VIII de Jovellanos a Posidonio (1802), en que no es el espectador quien admira la bóveda celeste, ni la mente la que emprende el vuelo del conocimiento: la muerte del hermano, que podría haberse vestido de memento mori, vanitas vanitatis y otro puñado de tópicos ya trasegados y poco acordes con la mentalidad ilustrada, se traduce mediante el código de lo sublime cósmico en un armonioso viaje del alma que recorre el mundo, asciende a las esferas y traspasando las fronteras del universo, encuentra su lugar en el cosmos y al Hacedor: «Oh sombra ilustre de Paulino, cuánto / de amargura y rubor te ahorró la muerte! / Libre está el alma, sí. Del globo entero / las regiones recorre contemplando / cómo la vida y la abundancia llenan / sus vastos climas; los remotos mares / surca veloz; desprecia entrambos polos / y a las altas esferas se remonta. / Ya en el éter se espacia; atravesando / los campos 
y tampoco convendría ceñir la cuestión al ámbito poético, pues la estética de lo sublime trasciende también a los géneros ${ }^{102}$, pero el demorado recorrido por lo sublime cósmico de Meléndez -cuya necesidad el lector paciente entenderápermite ubicar sin muchas dudas estos poemas de Meléndez en el primer estadio de dicha transición.

En este nutrido corpus de poemas entre 1780 y 1814, cuyos temas eran según Meléndez Valdés «la bondad de Dios, su benéfica providencia, el orden y armonía del Universo, y la inmensa variedad de seres que lo pueblan y hermosean» (OV, I: p. 67), que es donde Meléndez hace radicar la modernidad de la poesía filosófica europea que hace "las delicias de humanistas y filósofos", la confianza en la armonía universal, con sus implicaciones teístas, permanece intacta, en la línea del Whatever is, is right de Pope, frente a la representación problematizada, secular y psicológica de la experiencia de sublimidad, que con el tiempo se identificaría con la experiencia romántica de lo sublime.

Parafraseando a Nigel Glendinning, el poeta es optimista, porque aún encuentra respuestas. En la metafísica del infinito de Meléndez, signada por las ideas de inmensidad, eternidad y orden, la visión en soledad no produce al contemplador del cosmos melancolía, terror, inquietud, aflicción ni desasosiego - «the pain of absolute solitude» de que hablaba Burke-. Se trata de una soledad filosófica, conforme al certero título del poema Philosophic solitude, or the choice of a rural life de William Livingston (1747), en que la contemplación del universo desde el retiro en la oscuridad y el silencio permite la reflexión y la conexión del individuo con la naturaleza o alguna instancia superior. Aunque inicialmente atónito, abrumado, desfallecido, asombrado o sobrecogido, el yo finalmente percibe, admirado, el orden y el equilibrio, la grandeza, variedad, infinitud, inmensidad, energía, poder y

de la luz, sobre las lunas / de Herschel se encumbra; rápida las puertas / eternales penetra, y a los coros / querúbicos unida, allí extasiada / su patria encuentra y su Hacedor venera" (GMJ, OC, I: p. 299).

102. En el caso de Jovellanos, lo sublime se revela durante tres lustros (1790-1806), como una línea-fuerza que sostiene la expresión estética del paisaje, que se rastrea y analiza en el elogio de Ventura Rodríguez (1790), las Cartas del viaje de Asturias (1794-1795), las literarias escenas del diario (1793-1794), la epístola a Moratín (1796), los discursos en el Real Instituto (1794, 1799, 1800), los diálogos económicos (1799), la epístola poética a Posidonio (1802) y la Descripción del castillo de Bellver (1806). En su caso, lo sublime, sea cósmico, alpino o marítimo, y en muy diversos géneros literarios, presenta una alta rentabilidad, no solo retórica: como en un remozado cedat nunc, viene a enfatizar el arrojo titánico del sujeto ilustrado y la grandeza de su misión, que no es otra que dominar el mundo, convertir el locus horridus en útil y domesticado locus amoenus o dominar mediante la ciencia incluso al cosmos; y viene a demostrar su poder: el temor o la admiración que lo sublime de la Naturaleza despiertan en el espectador están orientados a subrayar el poder del sujeto que la somete. Ante el cosmos inmenso y armónico de origen neoplatónico y el paisaje escarpado y desmedido, el sujeto que contempla, sorprendido y maravillado o embargado por la inquietud o la melancolía, se crece para dominar, se sobrepone para intentar comprender y, si la razón ha de abdicar, se acoge a una argumentación trascendente o religiosa. LORENZO ÁlvAREZ, Elena. "El "curioso contemplador de la naturaleza”: la estética de lo sublime en los escritos literarios de G. M. Jovellanos». Iberoromania, 2016, 84, pp. 270-280. 
unidad de la Naturaleza y el Universo. Esta visión de un cosmos estable y reglado conduce a una explicación de carácter trascendente, religioso, que desemboca en el reconfortante reconocimiento de la existencia de una instancia superior que es causa y sostén del universo, de un gran fin que todo lo dota de sentido y permite al poeta comprender su lugar en el cosmos.

\section{BIBLIOGRAFÍA}

ABellán, José Luis. "La poesía filosófica: un capítulo de la historia de las ideas del siglo XVIII». En Homenaje a Juan López-Morillas. De Cadalso a Aleixandre: Estudios sobre literatura e historia intelectual españolas. Ed. J. Amor y Vázquez y A. David Kossoff. Madrid: Castalia, 1982.

AdDison, Joseph. The Spectator. Ed. Donald F. Bond. Londres: Oxford University Press, 1965.

Aguilar PiÑal, Francisco. «La poesía filosófica de Cándido María Trigueros». Revista de Literatura, 1981, 43, pp. 19-36.

Aguilar Piñal, Francisco. Un escritor ilustrado: Cándido María Trigueros. Madrid: CSIC, 1987.

ANDERSON, Lorin. "Charles Bonnet's Taxonomy and Chain of Being". Journal of the History of Ideas, 1976, 37.1, pp. 45-58.

ARCE, Joaquín. La poesía del siglo ilustrado. Madrid: Alhambra, 1981.

Blanco White, José María. Obra poética completa. Ed. Antonio Garnica y Jesús Díaz García. Madrid: Visor, 1994.

BONNET, Charles. Oeuvres d'histoire naturelle et de philosophie. Neufchâtel: [s. e.], 1779, 18 vols.

BozAl, Valeriano. «Sublime, neoclásico, romántico». En Burke, Edmund. Indagación filosófica sobre el origen de nuestras ideas de lo sublime y de lo bello. Murcia: Colegio de Aparejadores y Arquitectos, 1985, pp. 7-37.

BROOKE, John H. Science and Religion: Some Historical Perspectives. Cambridge: Cambridge University Press, 1991.

Cadalso, José de. Ocios de mi juventud. Ed. Miguel Ángel Lama. Madrid: Cátedra, 2013.

CAÑas Murillo, Jesús. «Sobre posbarroquismo y prerromanticismo en la literatura española del siglo XVIII». En Álvarez Barrientos, Joaquín y Checa Beltrán, José (eds.). El siglo que llaman Ilustrado. Homenaje a Francisco Aguilar Piñal. Madrid: CSIC, 1996, pp. 159-169.

CASO GONZÁLEZ, José Miguel. «Introducción general a la literatura del siglo XVIII». En Historia de la literatura española. León: Everest, 1995, pp. 39-41.

Clarke, Samuel. Traités de l'existence et des attributs de Dieu. Trad. M. Ricotier. [s. 1.]: 1744, 3 vols.

Clarke, Samuel. A demonstration of the being and attributes of God. Dublin: [s. e.], 1751, 5 vols.

Clarke, Samuel. A Demonstration of the Being and Attributes of God and Other Writings. Ed. Ezio Vailati. Cambridge: Cambridge University Press, 1998.

COLFORD, William E. Juan Meléndez Valdés: a study in the transition from Neoclassicism to Romanticism in Spanish Poetry. Nueva York: Hispanic Institute, 1942.

Demerson, Georges. Don Juan Meléndez Valdés y su tiempo. Madrid: Taurus, 1971, 2 vols. 
Duprey, Laura. "L'idée de chaîne des êtres, de Leibniz à Charles Bonnet". Dix-huitième siècle, 2011, 43, pp. 617-637.

EfFross, Susi Hilburn. "The influence of Alexander Pope in Eighteenth-Century Spain». Studies in Philology, 1966, 63, pp. 78-92.

FESS, G. M. «Meléndez Valdés' Vanidad de las quejas del hombre contra su hacedor and the Pensées of Pascal». Modern Language Notes, 1924, 39, pp. 282-284.

Fontenelle, Bernard Le Bovier de. Oeuvres complètes. París, 1769, 11 vols.

Forcione, Alban. «Meléndez Valdés and the Essay on Man». Hispanic Review, 1966, 34.4, pp. 291-306.

Froldi, Rinaldo. Un poeta illuminista: Meléndez Valdés. Milán: Cisalpino, 1967.

Gale, Monica R. (ed.). Oxford Readings in Classical Studies. Lucretius. Oxford: Oxford University Press, 2007.

GARCía CALDERÓN, Ángeles. "La poesía inglesa de la Naturaleza en el siglo XVIII y su influencia en Meléndez Valdés». Revista de Literatura, 2007, 138, pp. 519-541.

GARCía CALDERÓN, Ángeles. "Salomon Gessner y su influencia en Meléndez Valdés a través de Thomson». Futhark: Revista de Investigación y Cultura, 2007, 2, pp. 131-147.

GARCía CALDERÓN, Ángeles. "La unión entre ciencia y poesía en el primer cuarto del XVIII en Inglaterra». Alfinge, 2010, 22, pp. 119-141.

GaRCía CALDERÓN, Ángeles. «El ascendiente de Thomson y Saint-Lambert en los romances rurales de Meléndez Valdés». Hikma, Estudios de Traducción, 2011, 10, pp. 9-27.

GevreY, Françoise; Boch, Julie y HaquetTe, Jean-Louis (eds.). Écrire la nature au XVIIIe siècle: autour de l'abbé Pluche. París: Presses Paris Sorbonne, 2006.

GIACOMONI, Paola. Il laboratorio della natura: paesaggio montano e sublime naturale in età moderna. Milán: Franco Angeli, 2011.

GLENDINNING, Nigel. «Influencia de la literatura inglesa en España en el siglo XVIII». En La literatura española del siglo XVIII y sus fuentes extranjeras. Oviedo: Cátedra Feijoo, 1968, pp. 47-93.

Gómez Castellano, Irene. «De lo diurno a lo nocturno en la poesía de Meléndez Valdés». eHumanista, 2012, 22, pp. 252-271.

Gómez de Hermosilla, José. Juicio crítico de los principales poetas españoles de la última era. Valencia: Mallén y sobrinos, 1840.

Gutiérrez Díaz-Bernardo, Esteban. "Fray Luis de León en Meléndez Valdés». Revista de Estudios Extremeños, 1999, 55.3, pp. 797-846.

Haller, Oeuvres poétiques de M. Haller, traduites de l'Aleman [s. d.].

Hardie, Philip. Lucretian Receptions. History, the Sublime, Knowledge. Cambridge: Cambridge University Press, 2009.

HASKELL, Yasmin. «Breaking ground: scientific poetry in Enlightenment Rome». En Loyola's Bees: Ideology and Industry in Jesuit Latin Didactic Poetry. Nueva York: Oxford University Press for the British Academy, 2003, pp. 178-244.

HERR, Richard. The Eighteenth-Century Revolution in Spain. Princeton (NJ): Princeton University Press, 1969.

Hierocles. Commentaires des vers dorés de Pythagore. Londres, 1742.

JACOB, Margaret C. The Newtonians and the English Revolution 1689-1720. Ithaca: Cornell University Press, 1976.

JANOWITZ, Anne. "What a rich fund of images is treasured up here": Poetic commomplaces of the sublime universe». Studies on Romanticism, 2005, 44.4, pp. 469-492. 
JANOwITZ, Anne. "The Sublime Plurality of Worlds: Lucretius in the Eighteenth Century». Tate Papers, Spring, 2010, 13. http://www.tate.org.uk/research/publications/tate-papers/13/ the-sublime-plurality-of-worlds-lucretius-in-the-eighteenth-century.

Janowitz, Anne. «Sublime». En A Handbook of Romanticism Studies. Ed. Joel Faflak y Julia M. Wright. Chichester (Reino Unido): John Wiley \& Sons, 2012, pp. 55-67.

JONES, William Powell. The Rhetoric of Science: A Study of Scientific Ideas and Imagery in Eighteenth-century English Poetry. Berkeley: University of California Press/Londres: Routledge and Kegan Paul, 1966.

Jovellanos, G. M. Obras completas, t. II, Epistolario. Ed. José Miguel Caso González. Oviedo: IFESXVIII, 1986. Citado: GMJ, OC, II.

Jovellanos, G. M. t. VI, Diario. Ed. José Miguel Caso González y Javier González Santos. Oviedo: IFESXVIII, 1994.

Jovellanos, G. M. t. VII, Diario. Ed. Javier González Santos y M. ${ }^{a}$ Teresa Caso Machicado. Oviedo: IFESXVIII, 1999.

Jovellanos, G. M. t. IX, Escritos asturianos. Ed. Elena de Lorenzo y Álvaro Ruiz de la Peña. Oviedo: IFESXVIII, 2005.

Jovellanos, G. M. t. XIII, Escritos pedagógicos. Ed. Olegario Negrín Fajardo. Oviedo: IFESXVIII, 2010.

KENwOOD, Alun. A study of nature in some Spanish pre-romantic poets, with special reference to sources. Presented for the degree of Master of Arts at the University of Sheffield: 1966. Depositada en la School of Arts and Humanities.

KRAMER, Lawrence. "Recalling the sublime: the logic of creation in Haydn's Creation", Eighteenth-Century Music, 2009, 6.1, pp. 41-57.

Lama, Miguel Ángel. «La ordenación de las Poesías de Meléndez Valdés». En Juan Meléndez Valdés y su tiempo (1754-1817). Ed. Jesús Cañas Murillo, Miguel Ángel Lama y José Roso Díaz. Mérida: Editora Regional, 2005, pp. 183-200.

LeIBnitz, G. Essais de Theodicée sur la bontée de Dieu, la liberté de l'homme et l'origine du mal. Lausanne: 1770.

LOCKE, John. Essai philosophique concernant l'entendement humain... (trad. par M. Coste). Ámsterdam, 1774.

LOCKE, John. Ensayo sobre el entendimiento humano. Trad. de E. O'Gorman, pról. de José A. Robles y Carmen Silva. México: Fondo de Cultura Económica, 1999.

Longino. Sobre lo sublime. Ed. José García López. Madrid: Gredos, 1996.

Lorenzo Álvarez, Elena de. Nuevos mundos poéticos. La poesía filosófica de la Ilustración. Oviedo: IFESXVIII, 2000.

LORENZO ÁlVAREZ, Elena. «El "curioso contemplador de la naturaleza": la estética de lo sublime en los escritos literarios de G. M. Jovellanos". Iberoromania, 2016, 84, pp. 270-280.

Lovejoy, Arthur O. The Great Chain of Being. Cambridge: Harvard University Press, 1936.

LOVEJOY, Arthur O. La gran cadena del ser. Historia de una idea. Barcelona: Icaria, 1983.

LuCRECIO. De rerum, natura cum notis Thomae Creech. Londini, 1754.

MANDRELL, James. "The Literary Sublime in Spain: Meléndez Valdés and Espronceda". MLN, 1991, 106.2, pp. 294-313.

MANDRELL, James. "Lo sublime literario en la poesía española de los siglos XVIII y XIX: Meléndez Valdés y Espronceda». Ermanno CALDERA y Rinaldo FrOLDI (eds.). Entresiglos 2, Roma: Bulzoni Editore, 1993, pp. 207-216.

Meléndez Valdés, Juan. Obras en verso (ed. Juan H. R. Polt y Jorge Demerson). Oviedo: Cátedra Feijoo. Centro de Estudios del Siglo XVIII, 2 vols., 1981 y 1983. Citado: OV. 
Meléndez Valdés, Juan. Poesías selectas. La lira de marfil. Ed. John H. R. Polt y Georges Demerson. Madrid: Castalia, 1981.

MelÉndez Valdés, Juan. Obras completas. T. III. Epistolario. Ed. Emilio Palacios Fernández. Madrid: Biblioteca Castro, 1997.

MorRIS, David B. "Poetic Practice: varieties of the Religious Sublime. Imaginative devotion: Addison, Thomson, Young». En The Religious Sublime: Christian Poetry and Critical Tradition in 18th-Century England. Lexington: The University Press of Kentucky, 1972, pp. 131-154.

Nicolson, Marjorie Hope. Mountain Gloom and Mountain Glory: The Development of the Aesthetics of the Infinite. Ithaca (NY): Cornell University Press, 1959.

NieuwentyT, Bernard. L'existence de Dieu démontrée par les merveilles de la nature. París: J. Vicent, 1725.

Olay VALDÉs, Rodrigo. «Juan Meléndez Valdés: una carrera literaria en los circuitos del poder». En LORENZO ÁlVVAREZ, Elena de (coord.). Ser autor en el siglo XVIII. Gijón: Ediciones Trea, 2017, pp. 347-371.

ORs, Miguel d'. Más virutas de taller [2004-2009]. Valencina de la Concepción: Los papeles del Sitio, 2010.

Pascal, Blaise. Pensées de M. Pascal sur la religion et sur quelques autres sujets [s. 1., s. e., s. a.], 2 vols.

PeErs, E. Allison. "Milton in Spain». Studies in Philology, 1926, 23.2, pp. 169-183.

PEERs, E. Allison. "The Influence of Young and Gray in Spain". Modern Language Review, 1926, 21.4, pp. 404-418.

Pegenaute, Luis. «La recepción de Milton en la España ilustrada: visiones de El paraíso perdidom. En Lafarga, F. (ed.). La traducción en España, 1750-1830: lengua, literatura, cultura. Lleida: Universitat de Lleida, 1999, pp. 321-334.

Pérez Magallón, Jesús. «Una carta de Juan Tineo a Leandro Fernández Moratín». Castilla: Estudios de Literatura, 1993, 18, pp. 123-138.

Pluche, Noël-Antoine. Le spectacle de la nature. Paris: [s. e.], 1752, 9 vols.

PLuche, Noël-Antoine. Histoire du ciel [s. l., s. e., s. a.]), 2 vols.

Polignac, Melchior. Anti-Lucretius, sive de Deo et natura. Lugduni: Perisse, 1780.

Polt, John H. R. Batilo: Estudios sobre la evolución estilistica de Meléndez Valdés. Oviedo: Centro de Estudios del Siglo XVIII, 1987, pp. 313-314.

Pope, Alexander. Essay on Man. En The Poems of Alexander Pope. Edición de John Butt. Londres: Butler \& Tanner (University Paperbacks), 1965.

PORTER, James E. "Lucretius and the Sublime». En The Cambridge Companion to Lucretius. Cambridge: Cambridge University Press, 2007.

PORTER, James E. The Sublime in Antiquity. Cambridge: Cambridge University Press, 2016.

Quintana, Manuel José. «Noticia histórica y literaria de Meléndez». En MelÉndez Valdés, Juan. Poesías. Madrid: Imprenta Nacional, vol. I, 1820, pp. XV-LXIX.

RaCINE, Louis. La religión. Trad. Ranz Romanillos. Madrid: Imprenta Real, 1786.

Raillard, Matthieu P. "Deism, the Sublime and the Formulation of Early Romanticism in Juan Meléndez Valdés and José de Cadalso". Studies in Eighteenth-Century Culture, 2010, 39, pp. 131-150.

Rico García, José Manuel. "Construcción y sentido de El viaje al cielo del poeta filósofo de Cándido María Trigueros». En Actas del XIV Congreso de la AIH. Newark: Juan de la Cuesta, 2004, vol. III, pp. 459-467. 
Rodríguez De la Flor, Fernando. "La filiación neoplatónica de un poema de Meléndez Valdés». Dieciocho, 1980, 3.1, pp. 51-61.

RodríGuez SÁnCHEZ DE LEÓn, María José. "Los premios de la Academia española en el siglo XVIII y la estética de la época». Boletín de la Real Academia Española, septiembrediciembre 1987, tomo LXVII, cuaderno CCXLII, pp. 395-425.

Rodríguez-Moñino, Antonio (ed.). Juan Meléndez Valdés. Poesías inéditas. Madrid: Rae, 1954.

RutherforD, Donald. Leibniz and the Rational Order of Nature. Cambridge: Cambridge University Press, 1995.

SAlinas, Pedro. Jorge Manrique, o tradición y originalidad. Buenos Aires: Editorial Sudamericana, 1947.

SAlinas, Pedro. Ella y sus fuentes. En Teatro completo. Sevilla: Alfar, 1992.

SEMPERE Y GUARINOS, Juan. Ensayo de una biblioteca de los mejores escritores del reinado de Carlos III, t. IV. Madrid: Imprenta Real, 1787.

SHEEHAN, Jonathan. "After prophecy: the poetic Bible and the recuperation of the Old Testament. En The Enlightenment Bible. Princeton (New Jersey): Princeton University Press, 2005, pp. 152-160.

STAY, Benedicto Philosophiae versibus traditae libri VI. Romae: 1747.

TRías, Eugenio. Lo bello y lo siniestro. Barcelona: Seix Barral, 1982.

Trigueros, Cándido María. El poeta filósofo, o poesías filosóficas en verso pentámetro. Sevilla: Manuel Nicolás Vázquez, 1774-1778.

TuVESON, Ernest. "Space, deity and the "natural sublime"». Modern Language Quarterly, 1951, 12.1, pp. 13-19.

UTz, Johann Peter. Poetische Werke. Leipzig: Dyck, 1768.

UTZ, Johann Peter. Arte de ser feliz, dividido en cuatro epístolas morales en prosa, escrito en alemán: su autor: Utz. Con más otras dos epístolas, la una intitulada "La Riqueza y la Gloria", y la otra "El Amigo de los hombres", ambas escritas en el mismo idioma: su autor Gellert. Madrid: Imprenta de Pantaleón Aznar, 1787. 